\title{
Öteki Mekânlarda Sosyal Sorunlar: Bir Literatür Taramas1
}

DOI: $10.26466 /$ opus.773019

\author{
* \\ Dilara Ustabaşı Gündüz * - Esra Sağlam ** \\ * Dr. Öğr. Üyesi, KTO Karatay Üniversitesi, Sosyal ve Beşeri Bilimler Fakültesi, Konya/Türkiye \\ E-Posta: dilara.ustabasi@karatay.edu.tr \\ ORCID: 0000-0002-8184-8446 \\ ** Dr., Bilim, Sanayi ve Teknoloji Bakanlığı/TÜBİTAK, Ankara/Türkiye \\ E-Posta: esrasaglam1@yandex.com \\ ORCID: 0000-0002-5633-5366
}

Öz

Kentsel yoksulluğun, mekânsal ayrışmanın ve bunlara bağlı olarak sosyal dışlanmanın yoğun olduğu mekânlarda yaşanan sosyal sorunlar bu çalışmanın kapsamını oluşturmaktadır. Çalışmanın amaci; öteki mekânlardaki insanlarının yaşadıkları sosyal sorunları ortaya koymak ve bu sorunları sosyal politika bakış açısıyla değerlendirmektir. Nitel araştırma yöntemine uygun olarak Web of Science Core Collection endekslerinde taranan öteki mekân çalışmalarında, yoksulluk, kent yoksulluğu, sosyal dışlanma, sosyal içerme ve sosyal politika anahtar kelimelerinin başlıklarında yer aldı ̆̆g, son on yılda yayımlanan 42 makale derlenerek sosyal hizmet ve sosyal politika perspektifiyle içerik analizine tabi tutulmuştur. Yapılan analiz sonucunda slum, ghetto, squatter, favela, banliyö ve gecekondu gibi öteki mekânlarda rastlanan başlıca sorunların; kentsel yoksulluk, temel ihtiyaçların karşılanamaması, barınma ve altyapı hizmetlerinden yoksunluk, eşitsizlik, gecekondu turizmi, yoksulluğun temsili, sosyal dışlanma, toplumsal sapma ve toplumsal cinsiyet ayrrmcılı̆̆ı olduğu bulunmuştur. Bu sosyal sorunlarm çözülebilmesi ve sosyal bütünleşmenin, sosyal gelişmenin sağlanabilmesi için sosyal hizmet uygulamalarına ve uygulanabilir sosyal politika önerilerine ihtiyaç duyulmaktadır

Anahtar Kelimeler: kentsel yoksulluk, sosyal dışlanma, öteki mekân, sosyal hizmet, sosyal politika 


\title{
Social Problems in the Otherized Places: A Literature Review
}

\begin{abstract}
The scope of this study is the social problems experienced in urban spaces where urban poverty, spatial segregation and consecutively social exclusion are experienced intensely. The purpose of the study is to explore the social problems experienced by people in "otherized" places and to evaluate these problems from a social policy perspective. In accordance with the qualitative research method, 42 other place studies that were cited in the Web of Science Core Collection indexes and published in the last ten years and included the keywords of poverty, urban poverty, social exclusion, social inclusion, and social policy in their titles, and subjected to content analysis from a social service and social policy perspective. The results show that the main problems encountered in other places such as slum, ghetto, squatter, favela, suburban and gecekondu; urban poverty, deprivation from basic needs and infrastructure services, lack of housing, inequality, slum tourism, representation of poverty, social exclusion, social deviation and gender discrimination. In order to solve these social problems and to ensure social integration and social development, social work practices and applicable social policy recommendations are needed.
\end{abstract}

Keywords: urban poverty, social exclusion, other spaces, social work, social policy 


\section{Giriş}

Sosyal dışlanma hemen her toplumda yaşanan çok boyutlu bir sosyal sorundur. En basit tanımıyla toplumsal bütünlüğün dışında kalma ya da bırakılma durumunu ifade eden kavram (Sapancall, 2005, s.23), ekonomik krizin kalkınmaya olumsuz etkisi, giderek artan işsizlik, yoksulluk sorunu ve sosyal dayanışma ilişkilerinin zayıflamasıyla dezavantajı duruma gelen birey ve grupların sosyal bütünleşme sorunlarına vurgu yapmaktadır (Şahin, 2009, s.73). Sosyal dışlanmanın nedeni olarak sıkça karşılaşılan sorunlardan biri de kentsel yoksulluk olgusudur (Yılmaz, 2006; Yaşar, 2013; Özgökçeler ve Bıçkı, 2013). Kentsel yoksulluk, bireylerin kentsel alanlarda yaşamlarını sürdürebilmeleri için ihtiyaç duydukları gelirden, temel hizmetlerden, sağlıklı ve güvenli yaşam ortamından mahrum kalmaları, kent alanlarından dışlanmaları, eğitim, bilgi, karar alma yetkisi, vatandaşlık gibi temel haklardan yararlanamama gibi sorunları barındırmaktadır (Türkdoğan, 2003, ss.107-108). Sosyal dışlanma kavramının ekonomik yetersizlik ve yoksulluğun dışında farklı nedenleri de kapsayan tanımları da mevcuttur. Marshall (1999) sosyal dışlanma kavramını bireylerin daha geniş bir ölçekteki cemaatle veya toplumla sosyal bağlar kurmaktan yoksun bırakılmaları olarak açıklarken (s.150); Jehoel-Gijsbers ve Vrooman (2004) ise temel ihtiyaçlara ve hizmetlere erişememe yanında resmi ve gayri resmi sosyal ağlara katılamama, yetersiz sosyal destek, sosyal izolasyon, yetersiz kültürel entegrasyonu da kapsayacak şekilde açıklama getirmişlerdir (s.16). Irksal, dinsel, mezhepsel, fiziksel, ekonomik, kültürel, sosyal, yaşayış tarzı gibi farklılıkları sebebiyle bazı birey ve gruplar toplumun genelinden ayrı tutulmakta, kendilerine tuhaf davranılmakta, toplumda istenmemekte, ayrımcilığa maruz kalmakta, ötekileştirilmekte ve topluma eşit vatandaşlar olarak katılım sağlayamamaktadırlar. Bu eylemlerin geneli sosyal dışlanmanın farklı yansımaları olarak değerlendirilmektedir.

Yoksulluk, farklı sosyokültürel değerlere sahip olma, toplumun genelinden farklı yaşayış tarzı, farklı etnik, dini, mezhepsel mensubiyetlerin olması gibi sebeplerle bazı birey ve gruplar kentsel alanlarda istenmemekte ve ötekileştirilmektedirler. "Öteki" sözcügüüle anlatılmak istenen, "sözü edilen veya benzer iki nesneden önem ve konum bakımından uzakta olan"dır (http://www.tdk.gov.tr). Fabian (1999) "öteki"yi modern antropolojinin kavramsallaştırdığını ifade eder. Kavram uygar ve vahşi toplum arasındaki mesafeyi, farklıı̆ı̆ı, zıtlığı ifade etmede kullanılır (Karaküçük, 2004, s.77). Sosyal, 
ekonomik, kültürel, yaşayış tarzı gibi nedenlerle toplumun geneli tarafından sosyal dışlanma yaşayan birey ve gruplar kendi içlerinde kurdukları sosyal dayanışma ilişkileri ve bağ ile aidiyet kurma ihtiyaçlarını gidermekte ve çoğunlukla bir arada yaşama ve yerleşme eğilimi göstermektedirler (Ustabaşı Gündüz, 2018, s.126). Bu nedenle bu insanların yaşadıkları mekânların toplumun geneli tarafindan hakir görüldügüne ve sosyal dışlanma olgusunun zamanla mekânı da kapsayacak şekilde genişlediğine birçok çalışmada yer verilmektedir (Adaman ve Keyder, 2006, s.10; Gökçearslan Çifci, 2008, s.49). Literatürde mekânsal yarılma (Bıçkı, 2006), mekânsal dışlanma (Adaman ve Keyder, 2006; Deniz vd, 2016), mekânsal ayrışma (Buğra, 2008; İçli, 2008) gibi kavramlarla karşımıza çıkan bu olgu aslında ötekileşen, ötekileştirilen, sosyal ve diğer yönlerden dışlanmaya uğrayan bölge insanlarının yaşadıkları bölgeleri ifade etmektedir.

Mekânsal dışlanmanın ülkemizde gecekondu, kent çeperi, çöküntü, varoş gibi karşılıkları bulunmaktadır. Bu mekânlar yabancı literatürde slum, getto, squatter, suburban, shanty, skidrow, favela, bantustan, ranchos, bidonville gibi farklı isimlerle anılmaktadır. Bu çalışmanın başlığında yer alan "öteki mekânlar" kavramı ile adı her ne olursa olsun bu bölge insanlarının çeşitli nedenlerle deneyimledikleri kentsel yoksulluğun, sosyal sorunların ve sosyal dışlanma olgusunun yaşadıkları mekâna da yansıdığını kabul ederek bu mekânların genelini ifade etmek amacıyla kullanılmıştır.

Öteki mekân kavramı Asiliskender'in (2006, s.205) Kayseri kent merkezinin geçirdiği mekânsal değişimi konu edindiği çalışmasında ve Yeğenoğlu'nun (2003, s.53) turistik mekânın yerlinin kimliği ve gövdesi üzerinde yarattığı dönüşümlere dikkat çeken çalışmasında geçmektedir. Ancak yazarlar çalışmalarında bu kavramın tanımını doğrudan vermemiştir. Bu çalışmada kullanılan öteki mekân kavramı ile çoğu zaman kent merkezine uzakta veya kentsel alanda olsa dahi kent insanından izole bir yaşam süren, sosyal, kültürel, ekonomik ve diğer nedenlerle sosyal dişlanmaya maruz kalan ve bu nedenle kent merkezinde tutunamayanların yaşadıkları yerleşimlerin geneli ifade edilmektedir.

Sosyal dişlanma kavramının antitezi olarak sosyal bütünleşme ve sosyal içerme kavramları akla gelmelidir. Sosyal bütünleşme kavramı, toplumda birlik, dayanışma, uyum ve dengeye işaret ederken; sosyal içerme kavramı ise sosyal dışlanmayla mücadele için birey ve grupların herkes gibi topluma 
katılımlarının sağlanabilmesi, temel hizmetlerden faydalanabilmesi için siyasi irade tarafından alınan önlemler anlamına gelmektedir (Seyyar ve Genç, 2010, s.633). Öteki mekânlarda temel ihtiyaçların giderilememesi, temel refah hizmetlerine erişilememesi halinde bölgede yaşayan birey ve gruplar topluma katılamama, sosyal eşitsizliğe, sosyal adaletsizliğe maruz kalma gibi nedenlerle sosyal çözülme yaşayacaktır. Bu da toplumsal gelişme önünde büyük bir sorundur. Toplumsal gelişmenin sağlanabilmesi için toplumun her bir ferdinin herkes gibi topluma eşit katılım göstermesi ve insan onuruna yakışır bir yaşam sürebilmesi gerekmektedir. Bu nedenle kentsel yoksulluğun, ötekileşmenin, sosyal dışlanmanın önlenmesi ve dolayısıyla sosyal gelişmenin sağlanabilmesi için sosyal hizmet uygulamaları ve uygulanabilir sosyal içerme politikaları önem arz etmektedir.

Bu çalışma kapsamında öteki mekânların (getto, slum, squatter, skid row, favela, bantustan, shanty, ranchos, suburban, bidonville ve gecekondu) konu edinildiği uluslararası literatürde yoksulluk, kentsel yoksulluk, sosyal dışlanma, sosyal içerme ve sosyal politika anahtar kavramlarını başlı̆̆ında bulunduran son on yılda yayınlanan makalelerden içerik analiziyle ulaşılan sosyal sorunların çerçevesi belirlenmiş ve bu sorun alanları sosyal politika bakış açısıyla değerlendirmeye tabi tutulmuştur. Çalışmanın dünya ülkelerindeki öteki mekânlara dair bir çerçeve sunması, yaşanan sorunların tasnif edilmesi ve sosyal gelişmenin sağlanabilmesi için sosyal hizmet uygulamalarına ve uygulanabilir sosyal politikalara duyulan ihtiyaca vurgu yapması bakımından literatüre katkı sağlayacağı ve politika yapıcılara yol göstereceği düşünülmektedir.

\section{Yöntem}

Çalışma konusu kapsamında belirlenen anahtar kelimeleri başlığında barındiran ve son on yilda yayınlanan makalelere Web of Science Core Collection endekslerinde tarama yapılmıştır. Arama yapılan veri tabanları şunlardır: Science Citation Index Expanded (8.500 dergi), Social Sciences Citation Index (3.000 dergi), Arts \& Humanities Citation Index (1,950 dergi), Emerging Sources Citation Index (5.000 dergi), Book Citation Index (60.000 kitap), Conference Proceedings Citation Index (160.000 konferans bildiri kitabı). Bu veri tabanları, EBSCOhost, Elsevier BV, OCLC, Ovid, ProQuest, Scopus, Thomson Reuters, VINITI RAN, Emerald Insight, JSTOR, SAGE, Springer, Wiley- 
Blackwell, Taylor \& Francis, BMJ gibi birçok akademik yayımcı kuruluşun kataloglarını kapsamaktadır.

Veri tabanlarında öteki mekânlardan herhangi birini ve kentsel yoksulluk, yoksulluk, sosyal dışlanma, sosyal içerme, sosyal politika kavramlarını konu alan çalışmalara ulaşmak amaciyla gelişmiş aramada "ghetto, skidrow, shanty, squatter, slum, favela, bantustan, ranchos, suburban, bidonville veya gecekondu" anahtar kelimeleri ile "social inclusion, social exlusion, social policy, urban poverty veya poverty" anahtar kelimelerini; makale, kitap içi makale, kitap bölümü ya da konferans bildirisi başlığında birlikte içeren çalışmalar taranmıştır. Tarama sonucu toplam 51 makaleye ulaşılmıştır. Bu makalelerin 9 tanesinin tam metninin temin edilememesi sebebiyle toplamda 42 makale içerik analizine tabi tutulmuştur.

Tablo 1'de tam metnine ulaşılan makaleler kronolojik sıralanmıştır.

Tam metnine erişilen 42 makale bir klasörde kayıt altına alınmış ve sırasıyla her bir makalenin özet, yöntem, bulgular ve sonuç kısımları niteliksel okuma yoluyla ele alınmıştır. Niteliksel okuma sırasında alınan notlar araştırmacıya araştırma konusuyla ilgili verilerin organizasyonunda, çözümlenmesinde ve değerlendirilmesinde yol göstermektedir (Kümbetoğlu, 2012, s.149). Niteliksel okumayla 42 makalenin her birinin nitel, nicel ve karma metotların benimsenerek yazıldığı, farklı coğrafyalarda farklı sosyoekonomik ve kültürel dinamiklere sahip birey ve grupları örneklem edindiği, bölgesel ve küresel sorunların konu edinildiği görülmüştür.

İçerik analizinin benimsendiği bu çalışmada, derlenen makalelerin daha detaylı incelenerek, araştırma sorusunu açıklayan kavram ve temalara ulaşmak (Yıldırım ve Şimşek, 2008, s.89) hedeflenmiştir. Niteliksel okuma sürecinde alınan notlar, içerik analiziyle belirlenen öteki mekân çalışmalarında yoğunlaşılan sorun alanlarını ortaya çıkarma, tema ve kategorilere ayırma sürecinde faydalı olmuştur.

Tablo 1. İçerik analizine tabi tutulan çalsşmalarn yöntem, kapsam ve odakları

\begin{tabular}{llllll}
\hline & Çalışma & Yöntem & Şehir/Ülke & $\begin{array}{l}\text { Öteki } \\
\text { Mekân }\end{array}$ & Çalışma Odağı \\
\hline 1 & $\begin{array}{l}\text { Gulyani ve } \\
\text { Talukdar (2010) }\end{array}$ & Nicel & Nairobi/Kenya & Slum & $\begin{array}{l}\text { Yoksulluk, konut mülkiyeti, alt- } \\
\text { yapı erişimi, yaşam koşulları }\end{array}$ \\
\hline 2 & Murphy (2010) & Nitel & $\begin{array}{l}\text { Philedelphia ve } \\
\text { Pittsburgh/ABD }\end{array}$ & Getto & $\begin{array}{l}\text { Banliyölerin yoksulluğa ilişkin ti- } \\
\text { polojik sinuflandırılması }\end{array}$ \\
\hline 3 & $\begin{array}{l}\text { Salon ve } \\
\text { Gulyani (2010) }\end{array}$ & Nicel & Nairobi/Kenya & Slum & $\begin{array}{l}\text { Yoksulluk, ulaşım hizmetlerine eri- } \\
\text { şim, kent için seyahat problemleri }\end{array}$ \\
\hline
\end{tabular}




\begin{tabular}{|c|c|c|c|c|c|}
\hline & Çalışma & Yöntem & Şehir/Ülke & $\begin{array}{l}\text { Öteki } \\
\text { Mekân }\end{array}$ & Çalışma Odağı \\
\hline 4 & $\begin{array}{l}\text { Hipp ve } \\
\text { Yates (2011) }\end{array}$ & Nicel & $\begin{array}{l}25 \text { farklı metro- } \\
\text { pol/ABD }\end{array}$ & Getto & Kentsel yoksulluk ile suç ilişkisi \\
\hline 5 & Izugbara (2011) & Nitel & Nairobi/Kenya & Slum & $\begin{array}{l}\text { Kentsel yoksulluk ile erkekler arası } \\
\text { şiddet (eril şiddet) ilişkisi }\end{array}$ \\
\hline 6 & $\begin{array}{l}\text { Mullins ve Jones } \\
(2011)\end{array}$ & Nitel & $\begin{array}{l}\text { Indianapo- } \\
\text { lis/ABD }\end{array}$ & Slum & $\begin{array}{l}\text { Kentsel yoksulluğun ırkçılık ve et- } \\
\text { nik ayrımcılık ile ilişkisi }\end{array}$ \\
\hline 7 & Nofre (2011) & Nitel & $\begin{array}{l}\text { Barselona/İs- } \\
\text { panya }\end{array}$ & $\begin{array}{l}\text { Ban- } \\
\text { liyö }\end{array}$ & $\begin{array}{l}\text { Sosyal bütünleşme, kentsel eşitsiz- } \\
\text { lik, kültürel haklar, birlikte yaşam }\end{array}$ \\
\hline 8 & Zulu vd. (2011) & Karma & Nairobi/Kenya & Slum & $\begin{array}{l}\text { Yoksulluk, göç, temel hizmetlere } \\
\text { erişim, resmi olmayan sağlık hiz- } \\
\text { metleri }\end{array}$ \\
\hline 9 & Brodrecht (2012) & Nitel & Lima/Peru & $\begin{array}{l}\text { Squat- } \\
\text { ter }\end{array}$ & $\begin{array}{l}\text { Yoksulluğun sosyal sermaye ve } \\
\text { kolektif davranış ile ilişkisi }\end{array}$ \\
\hline 10 & Dürr (2012) & Nitel & $\begin{array}{l}\text { Mazatlan/Mek- } \\
\text { sika }\end{array}$ & Slum & $\begin{array}{l}\text { Kentsel yoksulluk, sosyal diş- } \\
\text { lanma, kent için seyyaliyet prob- } \\
\text { lemleri }\end{array}$ \\
\hline 11 & $\begin{array}{l}\text { Steinbrink, } \\
\text { M. (2012) }\end{array}$ & Nitel & $\begin{array}{l}\text { Cape Town/ } \\
\text { Güney Afrika }\end{array}$ & Slum & $\begin{array}{l}\text { Kentsel yoksulluk, yoksulluk kül- } \\
\text { türü, Slum turizminin gayriahlaki } \\
\text { içeriği }\end{array}$ \\
\hline 12 & Corboz (2013) & Nitel & $\begin{array}{l}\text { Montevideo/ } \\
\text { Uruguay }\end{array}$ & $\begin{array}{l}\text { Squat- } \\
\text { ter }\end{array}$ & $\begin{array}{l}\text { Yoksulluk kültürü, sosyal dış- } \\
\text { lanma, yoksullara karşı hegemo- } \\
\text { nik dışlayıcı söylem }\end{array}$ \\
\hline 13 & Frenzel (2013) & Nitel & $\begin{array}{l}\text { Rio de Jane- } \\
\text { iro/Brezilya }\end{array}$ & Favela & $\begin{array}{l}\text { Yoksulluktan kaçınmanın Favela } \\
\text { turizmindeki rolü }\end{array}$ \\
\hline 14 & $\begin{array}{l}\text { Simonelli } \\
\text { vd. (2013) }\end{array}$ & Nicel & $\begin{array}{l}\text { Buenos Aires/ } \\
\text { Arjantin }\end{array}$ & Slum & $\begin{array}{l}\text { Kentsel yoksulluk, barınma koşul- } \\
\text { ları, yaşam kalitesi, uyku kalitesi }\end{array}$ \\
\hline 15 & Awad (2014) & Nicel & Santiago/Şili & Getto & $\begin{array}{l}\text { Kentsel yoksulluk, damgalama, } \\
\text { sembolik adaletsizlik }\end{array}$ \\
\hline 16 & $\begin{array}{l}\text { Gulyani, Bassett } \\
\text { ve Talukdar } \\
(2014)\end{array}$ & Nicel & $\begin{array}{l}\text { Dakar/Senegal } \\
\text { Nairobi/Kenya }\end{array}$ & Slum & $\begin{array}{l}\text { Kentsel yoksulluk, eğitimsizlik, iş- } \\
\text { sizlik, yaşam koşulları, altyapı ve } \\
\text { kentsel hizmetlere erişim, barınma } \\
\text { kalitesi, suç }\end{array}$ \\
\hline 17 & Bengs vd. (2015) & Nitel & Vaasa/Finlandiya & $\begin{array}{l}\text { Ban- } \\
\text { liyö }\end{array}$ & Sosyal bütünleşme, sosyal içerme \\
\hline 18 & $\begin{array}{l}\text { Girbés-Peco } \\
\text { vd. (2015) }\end{array}$ & Nitel & Albacete/İspanya & Getto & $\begin{array}{l}\text { Yoksullukla mücadelede öğrenen } \\
\text { toplumun ve eğitimin rolü }\end{array}$ \\
\hline 19 & Hanrahan (2015) & Nitel & $\begin{array}{l}\text { Mumbai/Hindis- } \\
\tan \\
\text { Manila/Filipinler }\end{array}$ & Slum & $\begin{array}{l}\text { Az gelişmiş ülkelerdeki Slum'lara } \\
\text { yönelik Batı sömürgeciliğinin etki- } \\
\text { siyle şekillenen küresel kültürün } \\
\text { ve oryantalist anlayışın egzotik } \\
\text { çarpıtmaların Slum turizmine etki- } \\
\text { leri }\end{array}$ \\
\hline 20 & $\begin{array}{l}\text { Maitra ve } \\
\text { Rao (2015) }\end{array}$ & Nicel & $\begin{array}{l}\text { Kalküta/Hindis- } \\
\text { tan }\end{array}$ & Slum & $\begin{array}{l}\text { Yoksullukla mücadele politikala- } \\
\text { rında gıda güvenliğini sağlamanın } \\
\text { önemi }\end{array}$ \\
\hline
\end{tabular}




\begin{tabular}{|c|c|c|c|c|c|}
\hline & Çalışma & Yöntem & Şehir/Ülke & $\begin{array}{l}\text { Öteki } \\
\text { Mekân }\end{array}$ & Çalışma Odağı \\
\hline 21 & $\begin{array}{l}\text { Parikh } \\
\text { vd. (2015) }\end{array}$ & Nicel & $\begin{array}{l}\text { Ahmedabad/ } \\
\text { Hindistan }\end{array}$ & Slum & $\begin{array}{l}\text { Altyapı ve kentsel hizmetlere eri- } \\
\text { şim sorunlarına yönelik yatırımla- } \\
\text { rın Slum sakinlerinin özellikle de } \\
\text { kadınların refahındaki rolü }\end{array}$ \\
\hline 22 & Small (2015) & Nitel & Ülke geneli/ABD & Getto & $\begin{array}{l}\text { Ghetto sakini yoksullara yönelik } \\
\text { basmakalıp düşünce, yanlış ta- } \\
\text { nıma ve sansasyonalizm }\end{array}$ \\
\hline 23 & $\begin{array}{l}\text { Subbaraman vd. } \\
(2015)\end{array}$ & Karma & $\begin{array}{l}\text { Mumbai/Hindis- } \\
\tan \end{array}$ & Slum & $\begin{array}{l}\text { Kentsel hizmetlere erişim, hane } \\
\text { halkı içme suyu yoksunluğu, içme } \\
\text { suyu kalitesi, }\end{array}$ \\
\hline 24 & Ajlouni (2016) & Nicel & $\begin{array}{l}\text { Amman ve } \\
\text { Akabe/Ürdün }\end{array}$ & Slum & $\begin{array}{l}\text { Kentsel yoksulluk, işsizlik, eğitim- } \\
\text { sizlik, cinsiyet ayrımcılığı, yetersiz } \\
\text { ve kötü beslenme, sosyal dış- } \\
\text { lanma, kamusal dışlanma, sağlık } \\
\text { sı çevre koşulları, kentsel hizmet- } \\
\text { lere erişim sorunları, yetersiz sağ } \\
\text { lık hizmetleri }\end{array}$ \\
\hline 25 & Butz (2016) & Nicel & Ülke geneli/ABD & Getto & $\begin{array}{l}\text { Kentsel yoksulluk ile paternalizm } \\
\text { ilişkisi }\end{array}$ \\
\hline 26 & $\begin{array}{l}\text { De ve Nag } \\
(2016)\end{array}$ & Nicel & $\begin{array}{l}\text { Kalküta/Hindis- } \\
\text { tan }\end{array}$ & Slum & $\begin{array}{l}\text { Çocukları etkileyen kentsel yok- } \\
\text { sulluk ve temel hizmetlerden mah- } \\
\text { rumiyet ilişkisi, kast sisteminin alt } \\
\text { sınıflarının ve Müslüman azınlığın } \\
\text { sosyal dışlanma ve kentsel yoksul- } \\
\text { luk sorunları }\end{array}$ \\
\hline 27 & $\begin{array}{l}\text { Miklian ve } \\
\text { Birkvad (2016) }\end{array}$ & Nicel & $\begin{array}{l}\text { Ahmedabad/ } \\
\text { Hindistan }\end{array}$ & Slum & $\begin{array}{l}\text { Kentsel yoksulluk, göç, sosyal diş- } \\
\text { lanma, dini gruplar arası çıkar ça- } \\
\text { tışmaları }\end{array}$ \\
\hline 28 & $\begin{array}{l}\text { Palakshappa } \\
\text { ve Fiks (2016) }\end{array}$ & Nicel & Ülke geneli/ABD & $\begin{array}{l}\text { Ban- } \\
\text { liyö }\end{array}$ & $\begin{array}{l}\text { Banliyölerde yaşayan yoksul aile- } \\
\text { lere yönelik çocuk sağlığı hizmet } \\
\text { sunum sorunları }\end{array}$ \\
\hline 29 & Zhao (2016) & Nicel & Pekin/Çin & $\begin{array}{l}\text { Ban- } \\
\text { liyö }\end{array}$ & $\begin{array}{l}\text { Kentsel varoşlardaki yoksul halkın } \\
\text { arazi mülkiyeti sorunları }\end{array}$ \\
\hline 30 & $\begin{array}{l}\text { Turok ve Borel- } \\
\text { Saladin (2016) }\end{array}$ & Nicel & $\begin{array}{l}7 \text { farklı şehir/ } \\
\text { Güney Afrika }\end{array}$ & $\begin{array}{l}\text { Ban- } \\
\text { liyö }\end{array}$ & $\begin{array}{l}\text { Kentsel yoksulluk, gayrı resmi yer- } \\
\text { leşim, kentsel işgücü piyasası }\end{array}$ \\
\hline 31 & $\begin{array}{l}\text { Goudet } \\
\text { vd. (2017) }\end{array}$ & Nitel & Nairobi/Kenya & Slum & $\begin{array}{l}\text { Yoksulluğun çocuk beslenmesi } \\
\text { üzerindeki olumsuz etkileri, yeter- } \\
\text { siz beslenme, açlık }\end{array}$ \\
\hline 32 & Nisbett (2017) & Nitel & $\begin{array}{l}\text { Mumbai/Hindis- } \\
\text { tan }\end{array}$ & Slum & $\begin{array}{l}\text { Sanitasyon ve temiz su yetersizliği, } \\
\text { kirli yaşam alanları, konut darlığ } \\
\text { gibi sorunların Slum turizmi ama- } \\
\text { cryla gelen turistler tarafından gör- } \\
\text { mezden gelinmesi }\end{array}$ \\
\hline 33 & $\begin{array}{l}\text { Mwiti ve } \\
\text { Goulding (2017) }\end{array}$ & Nitel & Nairobi/Kenya & Slum & $\begin{array}{l}\text { Slum'larda yaşayan yoksul kadın- } \\
\text { ların yüzleştiği cinsiyet ayrımcılığ } \\
\text { ve kaynaklara erişim eşitsizliği so- } \\
\text { runları }\end{array}$ \\
\hline
\end{tabular}




\begin{tabular}{|c|c|c|c|c|c|}
\hline & Çalışma & Yöntem & Şehir/Ülke & $\begin{array}{l}\text { Öteki } \\
\text { Mekân }\end{array}$ & Çalışma Odağı \\
\hline 34 & $\begin{array}{l}\text { Schnake-Mahl } \\
\text { ve Sommers } \\
\text { (2017) }\end{array}$ & Nicel & Ülke geneli/ABD & $\begin{array}{l}\text { Ban- } \\
\text { liyö }\end{array}$ & $\begin{array}{l}\text { Banliyölerde yaşayan yoksul hal- } \\
\text { kın genel sağlık sigortası ve sağlık } \\
\text { hizmetlerine erişim sorunları }\end{array}$ \\
\hline 35 & Gowayed (2018) & Nicel & Kahire/Misır & Slum & $\begin{array}{l}\text { Kentsel yoksullukla mücadeleye } \\
\text { yönelik annelere verilen maddi } \\
\text { yardım ve çocukların okula gön- } \\
\text { dermeyi teşvik politikaları }\end{array}$ \\
\hline 36 & $\begin{array}{l}\text { Antuñano } \\
(2018)\end{array}$ & Nitel & $\begin{array}{l}\text { Mexico City/ } \\
\text { Meksika }\end{array}$ & Slum & Göç ile yoksulluk kültürü ilişkisi \\
\hline 37 & Guldi (2019) & Nitel & Britanya & $\begin{array}{l}\text { Squat- } \\
\text { ter }\end{array}$ & $\begin{array}{l}\text { Kitlesel düzensiz göç ile kentsel } \\
\text { yoksulluk ilişkisi }\end{array}$ \\
\hline 38 & $\begin{array}{l}\text { Habeeb ve Ja- } \\
\text { vaid (2019) }\end{array}$ & Nitel & $\begin{array}{l}\text { Dehradun/ } \\
\text { Hindistan }\end{array}$ & Slum & $\begin{array}{l}\text { İklim değişikliğine bağlı sel ve taş- } \\
\text { kın gibi doğal afetlerin Slum'larda } \\
\text { yaşayan yoksul hane halkı üzerin- } \\
\text { deki etkileri }\end{array}$ \\
\hline 39 & Oliveira (2019) & Nitel & $\begin{array}{l}\text { Paraniaba/Bre- } \\
\text { zilya }\end{array}$ & Favela & $\begin{array}{l}\text { Sel ve taşkınların Favela'larda ya- } \\
\text { şayanlar üzerindeki etkileri }\end{array}$ \\
\hline 40 & $\begin{array}{l}\text { Prayitno, Sari ve } \\
\text { Putri (2019) }\end{array}$ & Nicel & $\begin{array}{l}\text { Makassar/ } \\
\text { Endonezya }\end{array}$ & Slum & $\begin{array}{l}\text { Kıyı bölgelerdeki Slum'larda yaşa- } \\
\text { yanların arazi ve konut mülkiyeti, } \\
\text { altyapı ve kentsel hizmetlere eri- } \\
\text { şim sorunların çözmeye yönelik } \\
\text { kentsel dönüşüm politikaları }\end{array}$ \\
\hline 41 & $\begin{array}{l}\text { Prianto ve Ama- } \\
\text { lia (2019) }\end{array}$ & Nicel & $\begin{array}{l}\text { Malang/ } \\
\text { Endonezya }\end{array}$ & Slum & $\begin{array}{l}\text { Yoksulluğun giderilmesinde Slum } \\
\text { turizminin rolü }\end{array}$ \\
\hline 42 & $\begin{array}{l}\text { Omeraki Çekir- } \\
\text { dekci (2020) }\end{array}$ & Nitel & $\begin{array}{l}\text { Ankara ve İstan- } \\
\text { bul/Türkiye }\end{array}$ & $\begin{array}{l}\text { Gece- } \\
\text { kondu }\end{array}$ & $\begin{array}{l}\text { Göçmen ve yoksul gecekondu sa- } \\
\text { kinlerinin gecekondu evlerini ken- } \\
\text { dileri için yuvaya dönüştürmele- } \\
\text { rindeki mekânsal, sosyal, materyal } \\
\text { ve zamansal etmenler }\end{array}$ \\
\hline
\end{tabular}

Çalışma kapsamında aşağıdaki araştırma sorularına yanıt aranmıştır:

1. Taranan makalelerde öteki mekân türlerinden hangileri araştırmalara konu edilmiştir?

2. Öteki mekân çalışmalarında öne çıkan sosyal sorunlar nelerdir?

3. Öteki mekân çalışmalarında hangi hizmetlere ihtiyaç duyulduğuna yer verilmiştir?

İçerik analiziyle belirlenen öteki mekânlarda yaşanan sorunlar tema ve kategorize işlemleri tamamlandıktan sonra bulgular kısmında başlıklarla sınıflandırılmıştır. Çalışma kapsamında belirlenen sorular bu başlıklar altında cevaplanmıştır. Bulgularda belirlenen başlıklar ilgili makalelerden yapılan alıntılarla ve literatürle desteklenerek açıklanmaya çalışılmıştır. 


\section{Bulgular}

Öteki mekân sorunu ülkemizde, 1950'li yıllarda köyden kente göçle gelenlerin kent yaşamına çeşitli nedenlerle uyum sağlayamaması sonucu kent merkezine uzak, kentin çeperinde veya kent merkezinde olsa dahi kent insanından izole yaşam süren daha çok derme çatma meskenler inşa ederek, kır yaşantısını sürdürmeleriyle görünür hale gelmiştir. Ülkemizde sanayileşmeye bağlı göç hareketliliğiyle ortaya çıkan gecekondulaşma olgusu, farklı coğrafyalarda farklı isimlerle anılmakta ve farklı süreçlerle ortaya çkmaktadır. Çoğu zaman birbirleriyle benzer sorunlar yaşanan bu yerleşim alanlarındaki insanlar kent insanına göre dezavantajlı bir konumdadır. Bu çalışma kapsamında öteki mekânları konu edinen 42 makale içerik analizine tabi tutularak aşağıda başlıkları verilen sorun alanlarına ulaşılmıştır.

\section{Yapısal Sorunlar: Eşitsizlik ve Ekonomik Yoksunluk}

Dünya ekonomisindeki son yıllardaki büyüme rakamlarına rağmen, kent yoksulluğu metropollerin gittikçe artan temel sorunlarından biri olmaya devam etmektedir. Öteki mekânların oluşumunda merkezi rol oynayan ekonomik yoksulluğun eğitimsizlik, çocuk sayısı ve alınan bireysel kararlar gibi yoksul bireylerin kendisinden kaynaklandığı düşünülen mikro nedenlerinden bahseden oldukça kabarık bir literatürden bahsedilebilir. Bunun yanında, tüm çabalara rağmen önü alınamayan müzmin bir problem olarak görülen bu yoksulluğun ve gettolaşmanın arkasında yatan temel nedenin makro düzeydeki sosyoekonomik eşitsizlikler ve bu sistemin ürettiği yapısal sorunlar olduğu görüşü de yaygınlık kazanmaktadır (Şenses, 2006, 145). Piyasa odaklı ekonomi politikaları, ülkeler arası gelir dağılımındaki adaletsizlikler, yoksul ve zengin kesimler arasındaki uçurumun derinleşmesi, sosyal politikaların bir kamu aygıtı olarak silikleşmesi, devletlerin refah hizmetlerinin sunumu konusunda giderek sahneden çekilmesi, siyasal faktörler, firsat eşitsizliği, yatırım oranlarının ve işgücü piyasalarının yetersizliği gibi yoksul kişilerin iradeleri dışında makro düzeyde gelişen olaylar yapısal nedenler olarak isimlendirilmektedir (Erdoğdu ve Kutlu, 2014, s.72).

Yoksulluğa ilişkin bahsi geçen yapısal nedenlerin, içerik analizine tabi tutulan bazı makaleler tarafından da konu edinildiği görülmektedir. Bu bağlamda, Uruguay'ın Montevideo şehrindeki bir slum yerleşkesi olan La 
Chacha'da etnografik bir araştırma yürüten Corboz (2013), makro düzeydeki ekonomi-politik gelişmelerin düşük gelirli insanların günlük yaşamlarını büyük oranda etkilediğini ortaya koymaktadır. Uruguay'daki neoliberal politikalar sonucu, yüksek gelirli ve düşük gelirli işçi kesim arasındaki eşitsizlik büyümüş ve "yeni yoksullar" oluşmuştur. Bu yeni yoksullar kent çeperlerine doğru bir dağılım göstermişler ve kronik yoksulluk yaşayan marjinal toplumsal kesimlerle birlikte yaşamaya başlamışlardır. Benzer şekilde, sosyoekonomik eşitsizliklerin kayıt-dışı araziler üzerindeki etkilerinden bahseden Zhao (2016) da makalesinde, arazilerinin kentsel alandaki gayri resmi gelişiminin, yerel grupların piyasa ekonomisine geçiş bağlamındaki sosyoekonomik eşitsizliklere verdiği bir tepki olarak görülmesi gerektiğinden bahsetmektedir. Çin'in Pekin şehrindeki banliyölerde, imarsız konutlar ve mevzuatça tanınmayan illegal kapalı güvenlikli siteler olarak kendini gösteren kayıt dışı arazi kullanımını inceleyen Zhao, söz konusu konutların başta gelen faydalanıcılarının düşük gelirli insanlar olduğunu ifade etmektedir.

Analiz edilen öteki mekân çalışmalarında öne çıkan en önemli temalardan biri de bu mekânlarda yaşanan ekonomik sorunlardır. Yoksulluğun öteki mekânlarda yaşanan birçok soruna zemin hazırladığı konusunda toplum bilimleri literatüründe önemli ölçüde bir görüş birliği sağlanmıştır. Yoksulluk başta sosyal dışlanma olmak üzere, sağlık sorunları, eğitimsizlik, kayıt-dışı ekonominin yayginlaşması, suç oranlarının artması, gibi birçok sosyal sorunu tetiklemekte ve geniş yansımaları olan toplumsal problemlere neden olmaktadır (Fortujin ve Ostendorf, 2004, s. 239).

Analiz edilen makaleler arasında konunun bu boyutuna değinen bazı çalışmalar da bulunmaktadır. Bir öteki mekân olarak slum bağlamının sağlık üzerindeki etkisini ele alan Zulu vd. (2011), Kenya'nın Nairobi şehrindeki slum yerleşimlerinde yürüttükleri saha araştırmalarında, birçok slum sakini için yoksulluğun sağlık sorunlarıyla iç içe geçtiği sonucuna ulaşmışlardır. Kötü çevre şartları ve altyapı sorunları yanında, tedavi ve önleyici hizmetleri karşılayacak yeterli gelire sahip olamamak slum bölgelerinde sağlık sorunlarını olumsuz tetikleyen en önemli nedendir.

Benzer şekilde; Izugbara (2011) Kenya'nın Nairobi kentindeki iki slum mahallesinde yürüttüğü ve erkek şiddeti olgusunu ele aldığ1 etnografik saha araştırmasında, yoksulluğun erkeklerde görülen şiddet eğilimini artırdığını 
göstermektedir. Araştırmaya göre, slum erkekleri arasında sık görülen hırsızlık, soyulma, yaralanma gibi şiddet davranışları geçim kaynaklarının kısıtlılığ ile oldukça yakından alakalıdır.

Brodrecht (2012) ise, neoliberal çağda artan dişlanma ve yoksulluğun, dezavantajlı kesimlerin ekonomik kaynakları yanında sosyal kaynakların da sınırlandırmış olduğunu ifade etmektedir. Para, buluşma mekânları, gerekli teçhizat, organizasyon yeteneği, iletişim becerileri gibi çoğunlukla yoksulluktan kaynaklı sosyal sermaye eksiklikleri, toplumsal sorunlar çevresinde kurulabilecek ortak hareket etme kabiliyetini de zayıflatmış görünmektedir.

Dakar ve Nairobi slum mahallelerinde yaşanan yoksulluğu ve yaşam koşulları araştırdıkları makalelerinde Gulyani vd. (2014), iki mahalle arasında yoksulluk ve yaşam koşulları bağlamında çok ciddi farklar bulunduğunu ifade etmektedirler. Bulgularıyla diğer çalışmalardan ayrışan bu makalede ulaşılan sonuç, eğitim ve istihdamın daha düşük yoksulluk ve iyileştirilmiş yaşam koşullarına dönüşeceği fikrini sorgular niteliktedir. Çünkü daha iyi eğitimli Nairobi sakinleri daha kötü yaşam koşullarından mustarip iken, daha düşük eğitim düzeyine sahip olan Dakar sakinleri istihdam ve altyapı hizmetlerine ulaşım konusunda çok daha iyi bir noktada bulunmaktadırlar. Bu bulgu, yoksulluk olgusunun tek bir değişkenle açıklanamayacak oldukça karmaşık bir olgu olduğunu göstermesi açısından önemli bir gösterge olarak kabul edilmelidir.

Diğer yandan literatürde, yoksulluk ile eşitsizlik ve toplumsal cinsiyet arasında örtüşen yönlerden de bahsedilmektedir. Çeşitli boyutlarda maruz kalınan ayrımcilığın yoksulluk riskini özellikle etnik, sınıfsal ve toplumsal roller anlamında zayıf gruplarda yer alan bireyler aleyhinde artırdığı bilinmektedir (Öztürk ve Çetin, 2009, s.2672) Bu konuya değinen De ve Nag (2016), Kalküta'daki sosyal ve dini gruplar bakımından birbirinden farklı 23 slum bölgesinde yoksulluğun çocuklar üzerindeki etkisini araştırdıkları makalelerinde gelir ve temel hizmetlere ilişkin yoksunlukların, çocuğu olan hane halkları için çocuk sahibi olmayan hane halklarına göre daha belirgin olduğunu ortaya koymaktadır. Bunun yanında, çalışmanın bulgularına göre, slumlarda yaşayan çocukları etkileyen bu yoksulluğun etnik ve sınıfsal ayrımcılıkla da bağlantılı olduğu bulgusuna ulaşmışlardır. Müslüman ve kastların alt düzeyine mensup hane halklarl, Hindulara ve üst kastlara mensup olanlara k1yasla gelir ve temel hizmetlere erişim bakımından daha mahrum durumdadirlar. 
Günümüzde ekonomik yoksunluk yaşayan dezavantajlı kesimlere yönelik ülkeler bazında ve uluslararası kuruluşlar düzeyinde bir takım yoksullukla mücadele politikaları geliştirilmiştir. Ekonomik ve beşeri kalkınma stratejileri, yeniden dağıtım politikaları, kamu harcamaları ve dış yardımlar gibi çeşitli şekillerde karşımıza çıkan bu yöntemler yoluyla yoksulların fiziki ve beşeri sermayelerinin iyileştirilmesi ve tüketim olanaklarının artırılması amaçlanmaktadır (Şenses, 2006, s.217-260).

Bu bağlamda, içerik analizine tabi tutulan makaleler arasında, yoksulluğun azaltılması perspektifine değinen Gulyani ve Talukdar (2010) 1.755 hane üzerinde yaptıkları nicel araştırmalarında, Nairobi'nin slum mahallelerinde yaygın olan ev tipi mikro işletmelerin yoksullukla mücadeledeki rolünü ele almaktadır. Bulgular, mikro girişimcilik faaliyetlerinin yoksulluğu azaltmada başarılı olduğunu göstermektedir.

\section{Temel Hizmetlerden ve Sosyal Haklardan Yoksunluk}

Temel ihtiyaçlarını toplumun her bireyi gibi yeterince karşılayamayan insanların sağlıklı bir yaşam sürmeleri beklenemez. İnsanların yaşamsal ihtiyaçları olarak temiz suya erişim, güvenli ve yeterli gıda alımı, sağlıklı yaşam, güvenli barınma ve gelişimsel ihtiyaçları olarak eğitime erişim, istihdama katılım, ulaşım ve iletişim araçlarının kullanılabilmesi gibi birçok gereksinimleri bulunmaktadır. İçerik analizi yapılan makalelerin bazıları güvenli gıda temini ve yeterli beslenme ihtiyacina vurgu yapmaktadır (Goudet vd., 2016; Palakshappa ve Fiks, 2016). Goudet ve arkadaşları (2015) Nairobi gecekondularında yaptıkları bir araştırmada bölgedeki çocukların yetersiz beslenme riskiyle karşı karşıya olduklarını ve bunun da çocukların beslenme ve bilişsel gelişimleri üzerinde uzun vadeli olumsuz sonuçları olabileceğine değinmektedir. Bir başka çalışmada ise yoksullukla mücadele politikalarının düşük gelirli kentsel slum hane halklarının gıda güvenliğini artırmada başarılı olabileceğine vurgu yapılmaktadır (Maitra ve Rao, 2015). Gıda güvenliği ve yeterli gıda temini insan gelişimi için elbette önemli bir ihtiyaç olmakla birlikte temiz suya erişim de temel ihtiyaçların ve de insan haklarının başında gelmektedir.

Öteki mekan çalışmalarının beş tanesinde suya erişim sorunu konu edinilmiştir (Ajlouni, 2016; De ve Nag, 2016; Subbaraman vd., 2015; Goudet vd., 2016; Gulyani vd., 2014). Kartal (2009) savunmasız grupların, özellikle de bu çalışmada öteki mekan olarak adlandırdığımız çoğu zaman illegal yerleşim 
alanlarında yaşayan insanların ya da azınlıkların suya erişimlerinin bilinçli olarak engellendiğini ifade etmektedir (s.65). De ve Nag (2016) tarafindan Kalküta şehrinde 23 slum yerleşiminde yaptıkları araştırma sonucu bu görüşü destekler niteliktedir. Buna göre kast ve azınlıklar su, sıhhi tesisat ve drenaj hizmeti konusunda ayrımcllğa maruz kalmaktadır (s.754). Bu bulgu öteki mekân insanlarının temel hizmetlerden mahrum bırakıldığını ve sosyal adaletin toplumun her kesimi için geçerli olmadığını göstermektedir.

Goudet ve arkadaşları (2016) suyun en fazla rapor edilen risk faktörleri arasında yer aldığını ve su yetersizliğinin hijyen noktasındaki eksiklikleri de doğurduğunu ifade etmiştir. Bu durumun sağlık sorunlarına sebebiyet vermesi muhtemeldir. Bu doğrultuda sağlık hizmetlerinden faydalanabilmek de önemli bir temel ihtiyaç olarak karşımıza çıkmaktadır. Altı makalede sağlık hizmetlerine erişimin önemi ele alınmıştır. Bu makalelerden bazıları temel hizmetlerden yararlanamama halinde en fazla etkilenen grupların çocuklar ve kadınlar olduğunu belirtmiştir (Parikh, 2015; De ve Nag, 2016; Salon ve Gulyani, 2010). Schnake-Mahl ve Sommers (2017) çalışmalarında banliyölerde yaşayan $\mathrm{ABD}$ nüfusunun önemli bir bölümünde sağlık sigortasının olmadığına ve bakım hizmetlerine erişimde zorluklar yaşandığına değinmişlerdir. Ayrıca 2015 yılında "Uygun Bakım Yasası"nın yürürlüğe girmesiyle banliyö insanları için sigorta kapsamına girme ve sağlık hizmetlerine erişimde belirgin bir iyileşme yaşanmadığı, yasanın daha çok kentlerdeki yoksulların şartlarının iyileştirilmesinde etkili olduğuna değinmişlerdir.

Gulyani ve arkadaşları (2014) Kenya'nın slum bölgelerinde yaptıkları araştırma sonucunda Nairobi'de su erişimi, sağlık hizmetleri, elektrik hizmeti ve atıkların alınması hizmeti gibi altyapı hizmetlerinde ciddi yoksunluklar yaşandığını ifade etmişlerdir. Benzer şekilde Ajlouni (2016) yetersiz ve zayıf beslenme, sağlıksız çevre, su temini, elektrik ve temel sanitasyon tesislerinin eksikliği, yüksek hastalık prevalansı, yetersiz ve uygunsuz sağlık hizmetleri gibi sorunlarının varlı̆̆ına değinmiştir (s.113). Bu bulguların dışında Simonelli ve arkadaşları (2013) barınma kalitesinin, fiziksel sağlığı ve yaşam kalitesini doğrudan etkilediğini; Zulu ve arkadaşları (2011) gelir yetersizliği nedeniyle hizmetlere sınırlı erişim ve sağlık ihtiyaçlarını karşılamak için uygun olmayan düşük kaliteli ve çoğunlukla gayri resmi ve düzensiz sağlık hizmetlerine güvenmenin sonucu Nairobi slum bölgesinin insanlarında yüksek düzeyde morbidite, güvenilir ve uygun fiyatlı sağlık hizmetlerine düşük erişim ve yüksek ölüm oranlarının görüldüğüne değinilmiştir (s.196). Görüldüğü 
üzere makalelerde ele alınan sorunlar birbirlerini tetikleyen zincirler sorununu anımsatmaktadır. Yetersiz beslenme, sağlıksız çevre koşulları, suya erişememe, uygunsuz sağlık hizmetleri ve diğer temel hizmetlerden yoksunluğun hastalık riskini tetiklediği anlaşılmaktadır.

Temel hizmetlerden yoksunluğun insan hayatında çok daha olumsuz etkilerinin olduğu açıktır. Bununla birlikte sosyal haklardan dışlanmanın da yadsınamaz etkileri vardır. Sosyal dışlanma yaşayan birey ve grupların yerleşim alanlarının yerel ve kamusal refah hizmetlerinden yeterli ölçüde istifade edemediği ve bu nedenle bu insanların sosyal katılım, toplumsal aidiyet, sosyal bütünleşme gibi konularda sorunlar yaşadığı birçok araştırmada ele alınan konulardandır. Toplumsal yaşama katılım için gerekli olan sosyal haklardan yoksunluk birey ve grupların toplumla bütünleşmesi önünde önemli bir engeldir. Buna göre eğitim, sağlık, sosyal, kültürel faaliyet ve hizmetlerinden yoksun olma birey ve grupların kendilerini geliştirememeleri, topluma katılımlarının sınırlanması ile karşı karşıyadır. Bu konuda taranan makaleler arasında eğitim giderlerinin karşılanmasında ekonomik yoksunluğu (Gowayed, 2018), eğitimden yararlanamama (Parikh vd., 2015), eğitime erişim sorunu ve eğitimden dışlanmayı (Brodrecht, 2012; Girbés-Peco vd., 2015; De ve Nag, 2016) konu alan çalışmalara ulaşılmıştır. Subbaraman ve arkadaşları (2015) temel hizmetlerden yoksunluğun sağlığa yönelik olumsuz etkileri yanında eğitim, yaşam kalitesi, sosyal uyum ve insanların politik içerilmeleri konusunda olumsuz etkilerinin olduğuna değinmişlerdir. Brodrecht (2012) çalışmasında neoliberal çağda yoksulluğun ve dışlanmanın nasıl arttığını, toplu seferberliğin üzerine oturduğu sosyal sermayenin gelişimini nasıl zayıflattığı konusunu ele aldığı çalışmasında yoksulluk nedeniyle çocukların kamu eğitiminden dışlandığını, bunun karşısında Canto del Mar yerleşimcilerinin kolektif eylemi bu sorunun çözümü için bir yol olarak görmediklerine değinmiştir (s.864). Bu çalışmalarda yoksulluğun, temel hizmetlerden yararlanamamanın eğitime katılmaya da olumsuz yansımasının olduğu görülmektedir. Bu noktada bir başka çalışma eğitime katılımda sosyal yardımların önemine vurgu yapmıştır. Eğitime katılımı sürdürebilmek için ekonomik yetersizlikle mücadele noktasında şartlı nakit transferleri uygulamalarının önemli bir kaynak olduğuna değinen Gowayed (2018), sosyal yardım uygulamasının kadınlara yapılıyor olmasının hane içi eşitsizlikleri ve devletin sağlayacağı haklardan mahrum bırakılmış ilişkileri değiştirmediği için nakit desteğinin kadınları güçlendirmeye yetmeyeceğini de eklemiştir. 
İçerik analizinde karşılaşılan bir başka sorun ulaşım hizmetlerinden gelir yetersizliği nedeniyle yararlanamamaktır. Salon ve Gulyani (2010) Kenya, Nairobi'de slum yerleşimcilerinin seyahat seçeneklerinin sınırlı olduğuna ve bu insanların motorlu taşımacilık masrafını karşılama güçlerinin olmaması nedeniyle yürümek durumunda kaldıklarına değinmiştir. Bununla ilgili saha araştırmasında yetişkinlerin \%65'inin işe, çocukların \%96'sının okula yürüyerek gitmek zorunda kaldıkları sonucuna ulaşmışlardır. Çalışmada eğitim uzmanlarının yoksul çocukların karşılaştıkları hareketlilik engelini dengelemek için yerleşim yerlerinin ulaşım kısıtlamalarının okul seçimi, ulaşım için özel kupon ve sübvansiyon gibi özel çözümler üzerinde çalışılması gerektiği üzerinde durulmuştur. Bu anlamda bireylerin istihdam olanaklarına, çocukların da eğitime erişme sorunları ve çözüm noktasında yapılabilecekler çalışmada konu edinilmiştir.

Genel olarak sağlık, temiz su, yeterli güvenilir gıda, ulaşım gibi temel hizmetlerden faydalanamamanın ve eğitimi finanse etmede yetersiz gelirin diğer ifadeyle yoksulluğun eğitim alma noktasında olumsuz etkileri öteki mekan çalışmalarında ele alınan konular arasındadır.

\section{Altyapı, Barınma Sorunları ve Kentsel Dönüşüm}

Ülkemizde gecekondu sorunu olarak da ele alınan öteki mekân olgusu gerek dar gelirli bireylerin emek piyasasından dışlanması gerekse konut sorununa devletin duyarsız kalmasının bir sonucu olarak karşımıza çıkmaktadır (Şengül, 2003, s.47). Şehir sınırları içerisinde barınma ihtiyaçlarını karşılayamayan dar gelirli insanlar, yasal koşulların dişına çıkarak "gecekondu" denilen konut, mahalle ve bölge düzeyinde yerleşim birimlerini oluşturmuş̧lardır (Çakır, 2007, s.1). Bu yerleşimler, çoğunlukla sağlıklı yaşam koşullarına uygun olmayan, su-kanalizasyon gibi ihtiyaçları karşılayacak altyapıdan yoksun arazilerde yoğunlaşmıştır. Altyapı sorunları yanında, bu bölgelerdeki barınma mekânları da büyük oranda yeterli sayı ve nitelikte değildir (Ünal, 2018).

$\mathrm{Bu}$ araştırma kapsamında taranan makalelerden bazıları da öteki mekânlardaki barınma ve altyapı sorunlarını konu edinmişlerdir. İçerik analizine tabi tutulan makalelerden, Ürdün'ün iki slum bölgesinde sağlığın sosyal belirleyicilerini incelemek üzere Ajlouni (2016) tarafından yürütülen araştırmada da önemli sonuçlara ulaşılmıştır. Araştırma, slum sakinlerinin ciddi 
yoksulluk gibi birçok zorluğa maruz kaldığını; sağlıksız çevre, su temini, elektrik ve temel sanitasyon tesislerinin eksikliği, yüksek hastalık prevalansı gibi sorunlarının olduğunu göstermektedir.

Simonelli vd. (2013), Arjantin'de slum mahallelerinde yaşayan ve bir konut programından yararlanan 150 slum sakininin katılımıyla nicel ve nitel araştırma yöntemlerini kullanarak gerçekleştirdikleri saha araştırmasında, slum konutlarının uyku ve yaşam kalitesine etkilerini araştırmışlardır. Sonuçlar, temel barınma kalitesindeki minimum iyileşmenin slum sakinleri arasında uyku kalitesini ve yaşam kalitesini önemli ölçüde artırdığını göstermektedir.

Slum mahallerinde alt yapı hizmetlerinin sosyoekonomik etkilerini ele alan Parikh vd. (2015) ise, Hindistan' daki beş slum yerleşiminde gerçekleştirdikleri saha araştırmasından hareketle, altyapı hizmetlerinin sunumu ve yoksulluğun azaltılması arasında kayda değer bir ilişki olduğu sonucuna ulaşmışlardır. Bulgulara göre, söz konusu hizmetlerin sunumu, bunların eksikliklerinden en çok etkilenen kadınlar arasında eğitimde \%66'lık bir artışa neden olmakta, okuryazarlığ $\% 62$, geliri \%36 artırmakta ve sağlık maliyetlerini \%26 azaltmaktadır. Araştırma, slum mahallelerindeki yaşamları iyileştirmenin en etkin yolunun, sağlık, eğitim ve istihdam müdahalelerinden önce bu bölgelere yapılacak altyapı yatırımları olduğu sonucuna varmaktadır. Bu durum, öteki mekânların sorunlarına ilişkin yürütülen sosyal politika faaliyetlerinde dikkate alınması gereken önemli bir bulgu olarak karşımıza çıkmaktadir.

Hindistan'ın Dehradun şehrindeki slumların iklim değişikliği olaylarına, özellikle de sellere karşı duyarlılıklarını araştıran Habeeb ve Javaid (2019) de makalelerinde, slum nüfusunun afetlere karşı en kırılgan toplumsal kesimi oluşturduğunu ortaya koymaktadırlar. "Coğrafi Bilgi Sistemi" (GIS) mekânsal analizini kullanarak Dehradun'daki savunmasız slum mahallelerini haritalandırdıkları çalışmalarında araştırmacılar, slum nüfusunun iklim değişikliği olaylarına karşı büyük oranda savunmasız olduğu bulgusuna ulaşmışlardır. Bu bağlamda, kentsel dönüşüm çalışmalarının önemine değinen araştırmacilar, kentsel dönüşüm projelerinin arazi sahibi olmayan slum sakinlerinin de gözetileceği ve sosyal içermeyi önceleyen bir anlayışla planlanması gerektiğini ifade etmektedirler.

Günümüzde kent çeperlerine yayılmış öteki mekânlarda yaşanan alt yapı ve barınma sorunlarına yönelik bir çözüm olarak, bu alanlarının altyapılı, 
sosyal ve ticari alanlarla donatılmış ve konut sorunu olmayan, sağlıklı kent parçalarına dönüştürülmesi olarak tanımlanabilecek "kentsel dönüşüm" projeleri yaygınlık kazanmaktadır (Ataöv, Osmay, 2007, s.58). Taranan makaleler arasında öteki mekânlardaki yapısal sorunların çözümü için yürütülen kentsel dönüşüm çalışmalarının sosyal içerme yaklaşımıyla ele alınmasını öneren bir başka makale de Mullins ve Jones (2011) tarafından kaleme alınan makaledir. Kentsel dönüşüm projelerinin sınıfsal ve etnik eşitsizliklerinin yeniden üretiminde bir enstrümana dönüşebildiğinden bahseden yazarlar, tarihi mimarinin hiçbir izini taşımayan ve bulunduğu mekândaki toplum tarafından kullanılmayan yeni yapılanmalar ve bu yolla gerçekleştirilen kentsel dönüşüm uygulamalarının yoksulluk ve ırk hakkındaki kalıp yargıları yeniden ürettiğini ifade etmektedirler.

Taranan makaleler kapsamında kentsel dönüşüm olgusuna ilişkin ele alınan bir başka konu da gecekondu sakinlerinin ihtiyaç ve beklentileri doğrultusunda yapılacak iyileştirmelerdir. Ankara ve İstanbul'daki bazı gecekondu bölgelerinde etnografik yöntemle gerçekleştirdiği saha araştırması kapsamında Çekirdekçi (2020), yoksul göçmen kadınların bir evin yuvaya dönüştürülmesi bağlamındaki deneyimlerine odaklanmaktadır. Araştırmaya göre, altyapı eksikliklerinden ötürü ağır şartlar barındıran ev işleri, ataerkil kurallar ve mahremiyeti mümkün kılmayan konut yapıları gibi zorluklar toplumsal olarak damgalanmış yerleşim alanlarını yani gecekonduları geçici bir mesken haline getirmektedir. Katılımcların ev ideallerinin de bir bulgu olarak sunulduğu araştırmada, hükümetin toplu konut çalışmaları tasarlanırken yoksul tüketicilerin oyun alanları ve parklar dışında ailelerin kendi sebzelerini yetiştirebildikleri bahçeler gibi sosyalleşmesine izin verecek ortak alanların düşünülmesinin önemli olduğu vurgulanmaktadır.

\section{Gecekondu Turizmi ve Yoksulluğun Temsili Sorunu}

Bir kalkınma aracı olarak turizm, günümüzde özellikle az gelişmiş ve gelişmekte olan ülkeler için yoksulluğun azaltılmasında etkili dinamiklerden biri olarak görülmekte ve Dünya Bankası, Birleşmiş Milletler ve Dünya Sağlık Örgütü gibi birçok kurum ve kuruluş tarafından yoksullukla mücadelenin önemli bir enstrümanı olarak öne çıkarılmaktadır (Karacaer vd., 2017, s.34). 
İçerik analizi yapılan makalelerden ikisi (Prayitno vd, 2019; Frenzel, 2013) öteki mekânların en önemli sorun alanlarından biri olan yoksulluğun azaltılmasında turizmin oynadığı rolü ele almaktadır. Temel odak noktası, turizm içinde yer alan yoksullara firsatların oluşturulması ve yoksulların bölgelerinde yürütülen turizm faaliyetlerine katılımı ve katkısı olan "Yoksul yanlı turizm" yaklaşımına değinen Prayitno ve diğerleri (2019), nicel yöntemle yürüttükleri araştırmalarında sosyal sermaye ve turizm ile toplum yoksulluğu arasında ters orantılı bir ilişki olduğu sonucuna varmışlardır. "Yoksul Yanlısı Turizm" yaklaşımıyla yürütülen turizm faaliyetlerinin toplumun yoksulluk seviyesini azaltabildiğini ortaya koyan bu makale, katılımc turizm yaklaşımının öteki mekân sakinleri için ekonomik fayda yanında sosyal ve kültürel anlamda olumlu etkilerini göstermesi açısından da önemlidir.

Yeni bir fenomen olarak yükselen gecekondu turizminin yoksullukla mücadele noktasındaki rolünü inceleyen Frenzel (2013) ise çalışmasında, yoksulluğun azaltılmasında nicel göstergelerine odaklanan genel yaklaşımın aksine, yoksulluğun çok boyutlu karakterini açıklayabilen bir değerlendirmeye ihtiyaç duyulduğundan bahsetmektedir. Yazara göre, yoksulluk daha geniş bir ekonomi-politik bağlamında değerlendirilmeli ve siyasi-sosyal bir sorun olarak görülmelidir.

Az gelişmiş ülkeler için yeni bir turizm modeli olarak yorumlanan ve küresel güney ve kuzey ayrımını derinleştiren bir fenomen olarak karşımıza çıkan gecekondu turizmi konusunun taranan öteki mekan çalışmalarında en çok ele alınan konular arasında olduğu görülmektedir. Taranan makalelerden dört tanesi (Frenzel, 2013; Nisbett, 2017; Steinbrick, 2012; Dürr, 2012) doğrudan farklı boyutlarına değindikleri gecekondu turizmi konusunu irdelemişlerdir. Gecekondu turizmi genel olarak, mahrumiyet bölgelerine yapılan organize turlar (Frenzel, 2013, s.118) olarak tanımlanabilir. Burada amaç, varlıklı insanların çoğu zaman sosyal medya aracilığıyla uzaktan bildikleri ancak bizzat şahit olmadıkları yoksulluğun farkına varmaları ve gecekondu sakinlerinin yoksullukla mücadelelerinde destek olunmasıdır. Bu yönüyle söz konusu turizmin yoksullukla mücadelede etkili bir çözüm olduğunu düşünenler yanında sosyal dışlanmayı artırıcı ve etiketleyici bu faaliyetler ile öteki mekânlara mahkûm olmuş bireylere faydadan çok zarar verildiğini savunan birçok araştırmacı da bulunmaktadır (Yıldız ve Yıldız, 2018, s.982). 
Bu kapsamda, içerik analizi yapılan çalışmalardan Steinbrink (2012), 150 yıllık bir geçmişe sahip olan gecekondu turizminin izini sürdüğü makalesinde, Güney Afrika, İngiltere ve Amerika örneğinden yola çıarak, günümüzdeki gecekondu turizminin en önemli işlevlerinden birinin konunun kültürleştirilmesi olduğunu ifade etmektedir. Nisbett (2017) ise Hindistan'ın Mumbai şehrinin Dharavi isimli slum mahallesine yapılan turistik bir gezi özelinde yürüttüğü etnografik çalışmasında, gecekondu turizminin olası olumsuz etkilerine değinmektedir. Araştırmacı, zengin orta sınıf batılıların 'üstün' ve 'zengin' hissetmelerini sağlayan gecekondu turlarının yoksulluğu normalleştirip romantikleştirdiğini ve sosyal eşitsizliği meşrulaştırdığını ifade etmektedir. Ayrıca, bu turlar yoksulluk ve öteki mekânlar konusunu depolitize etmekte ve devletin yoksulluğun azaltılmasındaki sorumluluğunu göz ardı etmektedir. Benzer şekilde, Meksika' nın Mazatlan şehrinde etnografik bir araştırma yapan Dürr (2012) de, gecekondu turizminin, öteki mekânlara ve sakinlerine ilişkin mevcut kalıpyargıların sürdürülmesi ve gecekondunun bir turistik alan olarak korunması riskini artırdığını ifade etmektedir.

Gecekondu ve banliyö gibi öteki mekânların ve buralarda yaşam süren bireylerin temsili ve algılanışı konusu da araştırma kapsamında taranan makalelerde ele alınan konulardan biridir. Bu bağlamda, "Slumdog Millionaire" isimli film ve "Solemn Lantern Maker" isimli romandan yola çkan Hanrahan (2015), bu eserlerin Batı'da hâkim oryantalist anlayışa hizmet ederek slum yerleşimlerini heyecanl, egzotik ve çekici yerler olarak gerçeklikten uzak şekilde resmettiklerini ifade etmektedir. Yazara göre, yoksulluğu ve sosyal sorunları küresel ölçekte pazarlanan bir meta haline getiren bu anlayış, yeni sömürgeciliğin bir enstrümanı olarak işlev görmektedir.

Öteki mekânlar konusunda oluşturulan algıda etnografik araştırmaların rolüne değinen Small (2015) ise, günümüzde yürütülen saha araştırmaları yoluyla yoksul gruplara ilişkin yanlış temsiller ve kalıp yargılar oluşturulduğundan bahsetmekte ve bunu önemli bir etik problem olarak görmektedir.

Şili-Santiago'da yer alan "Bajos de Mena" isimli gettoda nitel yöntemle gerçekleştirdiği araştırmasında ise Awad (2014), yoksulluğun bir başka mecrada temsiline değinmektedir. Yoksulluk içerikli haberlerin yapım sürecinde yoksulların ve gazetecilerin rolünü ele aldığı makalesinde yazar, gazetecilerin siyasi ve sosyal görüşlerine uygun şekilde ve geniş kitlelere hitap eden, 
olumsuz ve sansasyonel hikayeler üretmeye yatkın oldukları sonucuna varmıştır. Günümüzde medya organlarının algı yönetimi noktasındaki gücü dikkate alındığında, yoksulluğun kendi gerçekliği dışında genellikle sansasyon yaratacak, marjinal ve olumsuz haberler üzerinden servis edildiğini gösteren bu çalışma öteki mekanlar açısından oldukça önemli bir noktaya dikkat çekmektedir.

\section{Sosyal Dışlanma Sorunu ve İçerme Çalışmalan İçin Çabalar}

Öteki mekan çalışmalarında sosyal dışlanma olgusu; ötekileşme, ayrımcılık (Miklian ve Birkvad, 2016), kentsel marjinalleşme (Corboz, 2013), izolasyon (Butz, 2016) gibi kavramlarla anılmaktadır. Taranan çalışmalar dışlanmanın farklı yönlerine değinmekle birlikte temelde eşitsizlik ve sosyal adaletsizliğe yapılan vurgu öne çıkmaktadır. Bununla birlikte taranan makalelerde mekânsal yarılma ya da mekânsal ayrışma örneklerine de rastlamak mümkündür. Buğra ve Keyder (2003) toplumdan dışlanma sürecini anlattıkları çalışmalarında mekânsal dışlanmaya nasıl varıldığını şu şekilde açıklamışlardir:

"Ekonomik dışlanma, yani sürekli bir işsizlik durumu giderek kültürel dışlanmaya yol açıyor, özellikle de bu insanlarm göçmen, farkh etnik kökenli oldukları durumlarda, siyasi dışlanmayla pekişiyor. Bu insanlar devletin kentlerin çeorelerinde yaptırdığı sosyal konutlarda ikamet ettiklerinde, olaya bir de mekânsal dışlanma eklemlenmiş oluyor."

"Kentler, toplumsal, siyasal, ekonomik, kültürel, mekânsal devinimlerin gerçekleştiği yerlerdir" (Akkoyunlu Ertan, 2007, s.60). Bu nedenle, toplumdaki yapısal eşitsizlikler, kent yaşamının getirdiği sorunlar ve çelişkiler bireylerde mekân aracilığıyla dışa vurulmaktadır (Şengül, 2003, s.47). Buradan hareketle içerik analiziyle benzer durumu dile getiren çalışmalara rastlanılmıştır. Brodrecht (2012) Canto del Mar'da katilımcı gözlem ve röportajlarla yaptığı araştırmasında sosyal dışlanmanın, düşük maliyetli konut ihtiyaçları dolayısıyla insanların diğer dışlanmış insanlarla dolu yerleşim yerlerine ayırdığ1 için konut izolasyonu şeklinde görünür olduğunu ifade etmiştir. Butz (2016) kent yoksullarının tarihsel olarak dezavantajlı bir grup olduğunu, ayrımclık, sosyal izolasyon ve sınırlı ekonomik firsatlarla uğraşmaya devam ettiklerini ifade etmiştir. Habeeb ve Javaid (2019) Dehradun slumlarında yaptıkları bir araştırmada sosyal dışlanma sorununun genellikle arazi mülkiyeti 
ile sınırlı olduğunu ifade etmişlerdir. Sosyal dışlanmanın bir çeşit mekânsal izolasyon olduğuna değinilen çalışmalarda dişlanmaya neden olan etkenin ekonomik yoksunluk olduğu anlaşılmaktadır.

İçerik analizine tabi tutulan çalışmalar arasında çeşitli şekillerde ayrımcılığa maruz kalan grupları konu edinen ve ayrımcılığın azaltılması gerektiği yönünde vurguda bulunan makaleler de yer almaktadır. Miklian ve Birkvad (2016) Hindistan'ın Ahmedabad şehrindeki Chandola'daki slum topluluğuyla yaptıkları araştırmalarında Hindu ve Müslüman topluluklar arasındaki sosyal tabakalaşma ve ayrımcılığın azaltılması gerektiğine değinmiştir. De ve Nag (2016) ayrımcllı̆ı̆n Müslüman ve kastların alt düzeyine mensup hane halklarında Hindu ve üst kastlara kıyasla gelir ve temel hizmetlere erişememeyle kendini gösterdiğine değinilmişlerdir. Buna yönelik istihdam, barınma, eğitim ve banka kredisi alma konularında azınlık ayrımclığının önüne geçmek için özellikle istihdama katılımları noktasında pozitif ayrımc1lık politikasının izlenebileceğini önermişlerdir. Bu çalışmada toplumsal sınıflaşma ve dini azınlık olma sebebiyle ayrımcılığa maruz kalındığı anlaşılmaktadır. Bu bulguların dışında farklı olarak De Antunano (2019) çalışmasında bir şehir eleştirmeni olan Jacobs'un Chicago'daki Afrikalı Amerikalıların deneyiminin tekil doğasını yansıtmada sessiz kalmasını ve siyah yoksulluğu ve ayrımcllı̆̆ konusuna değinmeyişini eleştirmiştir. Buradan ayrımcılığın ırk üzerine inşa edildiği ve birçok sosyal dışlanmaya maruz kalan grup gibi bu insanların da görmezden gelinmesi eleştirilmektedir.

Nofre (2011) ise, Barselona örneğinde banliyö bölgelerinde "öteki" yaratmanın bir aracı olarak kullanılan banliyö gece eğlenceleri ve bunların gençlik politikaları yoluyla üretilen yeni biçimlerini ele aldığı makalesinde, bu durumun yapısal bir sorun olarak banliyölerdeki sosyal kaynaşmaya yönelik olumsuz etkilerine değinmektedir. Barselona'da yerel yönetim tarafından son 30 yılda yürütülen gençlik politikaları yoluyla, banliyölerin merkezi yönetim tarafından dayatılan "İspanyol" kimliği karşısında yeniden Katalon'laştırılmaya çalışıldığı ve genç banliyö işçi sınıflarının gece eğlenceleri gibi sosyal ve kültürel faaliyetlerinin bu yönde organize edildiğinden bahisle yazar, bu durumun banliyö toplumunda yeni karşıtlıklar doğurduğunu ve sosyal dirençler ortaya çıkardığını ifade etmektedir. Nofre'ye göre Barselona'da kamusal alanda yürütülen ikili ve çatışmacı kimlik politikaları, alt sınıfların kültürel tüketim alanlarının gettolaşmasına ve kentsel eşitsizliklerin ye- 
niden artmasına zemin hazırlamaktadır. Getto oluşumlarında bölge sakinlerinin kendi tercihlerinden bağımsız birtakım faktörlerin etkili olduğunu savunan görüşleri haklı çıkaran bu makale ile sınıfsal sosyal dışlanma olgusunun silikleştiği Batı ülkelerinde, uygulanan yanlış politikalar nedeniyle yeni eşitsizliklerin ve yeni gettoların doğduğu ifade edilmektedir.

Çalışmalar genel olarak incelendiğinde ayrışmaya, kentsel eşitsizliğe, ötekileşmeye yol açan nedenler üzerinde durulmuş ve sosyal bütünleşmenin sağlanabilmesi için toplumsal kapsayıcilığı olan sosyal içerme politikalarına ihtiyaç duyulduğuna vurgu yapılmıştır.

\section{Toplumsal Sapma ve Cinsiyet Ayrmcılı̆̆}

Öteki mekan çalışmalarına genel olarak bakıldığında sosyoekonomik düzeyin, istihdama katılımın düşük olduğu, toplumun genelinden uzaklaşan ancak kendi içlerinde dayanışma ve bütünleşmenin olduğu görülmektedir (Ustabaşı Gündüz, 2018; Genç vd. 2015; Alptekin vd., 2013). Toplumun genelinin sosyal kabulünden uzak olan bu birey ve grupların kendi içlerinde geliştirdikleri aidiyet duyguları, topluma karşı kurulduğundan sosyal barışın toplum geneline yayılması ve dolayısıyla toplum olarak sosyal bütünleşmenin sağlanması mümkün olamamaktadır. Wacquant (2015) Kent Paryaları adlı çalışmasında Fransız işçi banliyöleri ve siyah Amerikan gettosunun ahlaksızlığın, suçun hüküm sürdüğü, mahallelerin nüfus yapısına işleyen güvensizlik nedeniyle bu mekânlardan uzak durulması gerektiğine dair büyüyen algının baskıcı dehşet iklimi yarattığına değinerek kamusal alanın yok olmaya yüz tuttuğuna dikkat çekmiştir (s.229). Türkdoğan (2015) Gecekondu ve İnsan: İstanbul Varoş Kültürü adlı çalışmasında sokak çocukları sorununun gecekondu kökeninden kaynaklandığını, bununla birlikte yoksulluk, gelir darlığı, istihdama katılamama, denetimsiz aile tutumu, sağlıksız sosyalleşme ve başıboş yaşantı biçiminin sapkın davranışlara zemin hazırladığına değinmiştir (s.106). Bu çalışma kapsamında öteki mekânlarda sapma davranışları konusuna değinen makaleler belirlenmiştir (Hipp, 2011; Izugbara, 2011; Miklian ve Birkvad, 2016).

Izugbara (2011) Kenya'nın Nairobi kentinde Koh ve Viwa isimli iki slum yerleşiminde yaşayan insanlarla yaptığı araştırma sonucunda aile içi şiddetin, geçim kaynaklarının kısıtlılığı ile yakından ilgili olduğunu ve katılımcı 
erkeklerin toplumdaki hırsızlık, soyulma, yaralanma gibi şiddet davranışlarını genellikle yoksullukla ilişkilendirdiklerini tespit etmiştir. Bunun üzerine yazar, yoksul erkeklerin şiddeti azaltmalarını destekleme, toplumsal cinsiyet eşitliği ve barışın inşasına katkıda bulunmak için onlara iyileştirilmiş geçim olanakları sağlanması gerektiğine ve bunun da mevcut şiddet önleme programlarında dikkate alınması gerektiğine vurgu yapmaktadır. Miklian ve Birkvad (2016) Hindistan'ın Ahmedabad şehrindeki Chandola'daki slum topluluğuyla yaptığı araştırmada Hindistan'daki çatışma dinamiklerinin ayrımcilık, yoksulluk ve şiddet algısını nasıl pekiştirdiğini ve bunlarla nasıl mücadele ettiğini gösteren unsurlar üzerinde durmuşlardır. Bu çalışmada şiddet konusunun ele alındığ kapsamda yoksulların toplumsal liderlik ile uyum sağladığını iddia eden literatürün sorgulanması gerektiğine değinilmiş. Bunun nedeni olarak Chandola'nın yoksul Hindular ve Müslümanlarının klasik Hindu-Müslüman düşmanlığının dişında kalmak isteği ve aralarındaki iş birliğini açıklamada literatürün yetersiz kaldığ ifade edilmiştir. Çalışmada ayrıca sosyal ve fiziksel hareketlilik eksikliğinden kaynaklanan ötekileşmenin şiddetin bir göstergesi olduğu ve yerel yönetimlerin yetersizliği sebebiyle ayrımclık ve savunmasız olma halinin çatışmalarda itici güç olduğu ele alınmiştır.

Genel görüşlerden farklı olarak Hipp ve Yates (2011) Amerika'da 25 şehre ilişkin kentsel yoksulluk ile suç ilişkisini çalıştıkları makalelerinde, yoksulluk oranlarının yüksek olduğu mahallelerde suç oranlarında keskin bir artışa rastlanmadığına değinmişlerdir.

İçerik analizi yapılan makaleler arasında toplumsal cinsiyet eşitsizliğine dair bulgular barındıran çalışmalar da yer almaktadır. Bunlardan biri Kenya, Nairobi'de 1751 hane ve dört yaş üstü 4375 slum sakiniyle gerçekleştirilen araştırma sonucunda karşımıza çıkmaktadır. Bölge sakinlerinin motorlu taşımacılık ücretlerini karşılayamamaları nedeniyle uzun mesafelerde yürümek zorunda kaldıklarına değinilen çalışmada kadınlar ve çocukların erkeklere göre bu durumdan orantısız bir şekilde daha fazla etkilendiğine değinilmiştir (Salon ve Gulyani, 2010). Parikh ve arkadaşları (2015) Hindistan'daki beş slum yerleşiminde 500 hane halkıyla yaptıkları araştırmada özellikle kadınların refahı için altyapı yatırımının kritik olduğu, temel refah hizmetlerinin sağlanmasının yoksulluk yükü altında en fazla ezilen grup olarak kadınların faydalanmalarını sağlayacağına değinilmiştir. Mwiti ve Goulding (2017) Kenya, Nairobi'de Kibera ve Mathare slum mahallelerinde bulunan beş farklı 
Chama grubuyla yoksulluk içinde yaşayan kadınların deneyimlerini incelemeyi amaçladıkları çalışmada cinsiyet, sınıf ve etnisite gibi güç ilişkileri ve özel sosyal koşulların kadınların deneyimlerini ve kararlarını şekillendirdiğine değinilmiştir. Ajlouni (2016) Ürdün'de Amman ve Akabe'de iki slum bölgesinde yaptığı araştırma sonucunda toplum temelli kadın güçlendirme programlarının geliştirilmesi ihtiyacına vurgu yapmıştır. Bu çalışmaların genelinde kadınların yoksulluğu daha derinden deneyimledikleri, zorlu koşullar karşısında diğerlerine göre daha dezavantajlı konumda oldukları ve güçlendirilmeleri gerektiğine dair bulgular yer almaktadır.

\section{Sonuç}

Bu çalışmada, Web of Science Core Collection endekslerinde taranan ve son on yilda yayınlanan yoksulluk, kent yoksulluğu, sosyal içerme, sosyal dışlanma ve sosyal politika anahtar kelimelerini başlıklarında içeren 42 öteki mekân çalışması içerik analizine tabi tutularak farklı coğrafyalardaki öteki mekânlarda yaşanan sorunların profili ortaya çıkarılmıştır. Öteki mekân çalışmalarına genel olarak bakıldığında 21 çalışmanın nitel, 19'unun nicel ve 2 'sinin de karma metot benimsenerek çalışıldığı görülmüş̧ür. Çalışmaların 24 'ü slum yerleşim alanlarında, 6'sı getto, 6'sı suburban diğer deyişle banliyö, 4'ü squatter (ki bunlardan biri Türkiye'de İstanbul ve Ankara gecekondu semtlerinin olduğu çalışmadır) ve kalan iki çalışma da favela yerleşim alanında yapılmıştır. Taranan 42 makaleden 7 'sinin saha araştırması Kenya Nairobi'de gerçekleştirilmiştir. 7 makale Hindistan'ın farklı şehirlerinde, 7 makale Amerika Birleşik Devletleri'nin farklı şehirlerinde gerçekleştirilmiştir. Güney Afrika, İspanya, Brezilya ve Endonezya'da ikişer çalışma; Meksika, Peru, Uruguay, Arjantin, Şili, Ürdün, Finlandiya, Britanya ve Çin'de birer çalışma yürütülmüsstür. Kenya Nairobi' de gerçekleştirilen çalışmaların geneli ekonomik yoksunluk üzerine yoğunlaşırken, Amerika Birleşik Devletleri'nin farklı şehirlerinde çalışılan makalelerin odağı daha çok ırkçılık, etnik ayrımcllık, kent yoksulluğu, sağlık hizmetlerinden yararlanamama ve suç konularında yoğunlaşmıştır. Hindistan'ın farklı şehirlerinde saha araştırması yürütülen 7 çalışmada ise altyapı ve kentsel hizmetlere erişim sorunu, temiz içme suyuna erişim sorunu, dini gruplar arası çıkar çatışmaları ve Hindistan'ın yoksul öteki mekânlarının slum turizmine malzeme edilerek gerçekliğin göz 
ardı edilişi işlenmiştir. Çalışmaların bu üç ülkede yoğunlaşıyor olması bu ülkelerin öteki mekânlarındaki sosyal sorunların rahatsız eden boyutlara vardığını göstermektedir.

Kenya'nın başkenti Nairobi'de saha araştırması yapılan 7 çalışmanın her biri insanların temel ihtiyaçlarını karşılayamadıklarını ve kentsel yoksulluğun yüksek düzeyde hissedildiğini vurgulamaktadır. Bu çalışmalarda beslenme, barınma, resmi sağlık hizmetlerinden yararlanamamanın yanında altyapı hizmetlerinin yetersiz olması, ulaşım giderlerini karşılayamama, eğitime erişememe, cinsiyet ayrımcllığı ve aile içi şiddeti de ele alınan sosyal sorunlardandır. Hindistan'ı örneklem alan çalışmalar da Nairobi'de ulaşılan sonuçlarla benzer nitelik taşımaktadır. Buna göre çalışmalarda yoksul öteki mekân sakinlerinin temiz suya erişim, alt yapı ve diğer temel hizmetlere duydukları ihtiyaca dikkat çekilmiştir. Bu bulgulardan hareketle temel yaşamsal ihtiyaçları karşılanmayan ve toplumun her bireyi gibi temel refah hizmetlerinden eşit bir şekilde yararlanamayan birey ve grupların insan onuruna yakışır sağlıklı bir yaşam sürmelerinin söz konusu olamayacağı söylenebilir. Bu şartlar altında öteki mekânlarda yaşayan birey ve grupların topluma aidiyet duygusu beslemeleri, topluma katılımları, toplumsal bütünleşmenin ve toplumsal barışın sağlanması mümkün değildir. Neoliberal ekonomi politiğinin Kenya gibi sahra altı ülkelerde rekabeti ve yoksulluğu çok daha kızıştırdığı düşünüldüğünde bu ülkelerin sosyal politikalara ve dolayısıyla sosyal hizmet uygulamalarına ayıracağı kaynağı sınırlandırmaktadır. Hindistan, sahip olduğu kast sistemi, gelir dağılımı adaletsizliği, kaynakların eşitsiz ve dengesiz dağıtımı gibi nedenlerle ülkenin en gelişmiş ve en yoksul mekânları arasındaki uçurumun giderek derinleştiği bir ülkedir. Burada yapılan çalışmalarda temel ihtiyaçların karşılanamaması, kentsel hizmetlerden faydalanamama, dini gruplar arasında çatışmanın yaşanması gibi sorunlara odaklanılmıştır. Hindistan'daki makro düzey bir sorun olan kast sisteminin başlı başına ayrımcı uygulamalara neden olduğu açıktır. Bu ayrımcı, adaletsiz yaklaşımdan en fazla ülkedeki azınlıkların ve alt kastlara mensup birey ve grupların etkilendiği görülmektedir. Sosyal adaletin toplumun her kesimi için aynı düzeyde işlemiyor oluşu bu toplumlarda sosyal gelişmenin ve toplumsal kalkınmanın önünde ciddi bir engeldir. XXI. yüzyılda kast sistemi gibi ayrımcı makro düzey uygulamaların toplumsal gelişme hedefi doğrultusunda sorgulanabilir olması gerekmektedir. Her şeyden önce insanların temel yaşamsal ihtiyaçlarının karşılanabilmesi ardından kentsel altyapı hizmetleri ve diğer 
sosyal haklardan yararlanabilmeleri için kamunun sosyal politika ve yerel yönetimlerin sosyal hizmet uygulamaları konusunda sorumluluk almaları gerekmektedir.

Sosyal politika perspektifiyle ele alınan bu çalışma öteki mekânlarda yaşanan sosyal sorunlara odaklanmakta ve toplumsal kalkınma ve sosyal gelişmenin sağlanabilmesi için gerekli içermeci önlemlere vurgu yapmaktadır. Mekânsal ayrışma, kentsel yoksulluk, sosyal dışlanma ve bunlara bağlı ortaya çıkan sorunların daha çok yapısal nitelikte olduğu, ekonomik yoksunluk ve toplumsal eşitsizliklerin buna bağlı ortaya çıktı̆̆ı anlaşılmaktadır. Kent içi yatırım farklılıklarının, sosyal refah hizmetlerine sınırlı erişimin ya da bu hizmetlere erişememenin, düşük sosyoekonomik ve eğitim düzeyinin, istihdama katılamamanın, toplumsal sapma sorunlarının, cinsiyet ayrımcılığının belirlendiği öteki mekân çalışmalarında bu bölge insanlarının en önemli ve öncelikli karşılanması gereken ihtiyaçlarının temel yaşamsal ihtiyaçları olduğu görülmektedir. Güvenilir gıdaya, temiz suya, altyapı ve diğer kentsel hizmetlere erişebilmeleri sağlandıktan sonra eğitim, sağlık gibi sosyal refah hizmetlerinden faydalanabilmeleri gerekmektedir. Tüm bu olanaklara sahip olmanın toplumsal bütünleşmenin sağlanmasına zemin hazırlayacağı düşünülmektedir. Ülkelerin her bir vatandaşına insan onuruna yakışır şekilde yaşamlarını sürdürebilmeleri ve topluma katılım sağlayabilmeleri için gerekli imkânları sunabilmeleri, vatandaşlarının toplumsal aidiyetlerini ve ülkeye olan bağlılıklarını arttıracaktır. Bu anlamda sosyal adaletin toplumun her kesimine yayılması sosyal bütünleşmenin, sosyal barışın ve sosyal gelişmenin sağlanabilmesi için bir zorunluluktur. Bu nedenle uygulanabilir sosyal politikaların ve koruyucu, önleyici, iyileştirici ve geliştirici sosyal hizmet uygulamalarının hayata geçirilmesi önem taşımaktadır. 


\title{
EXTENDED ABSTRACT
}

\section{Social Problems in the Otherized Places: A Literature Review}

\author{
* \\ Dilara Ustabaşı Gündüz - Esra Sağlam \\ KTO Karatay University, TUBITAK
}

Social exclusion is a multidimensional social problem experienced in almost every society and according to its simplest definition, it is a process of impairing social cohesion and denying opportunities for social participation (Sapancal1, 2005, p.23). One reflection of the mentioned problem is the phenomenon of "urban poverty". This form of poverty involves problems such as low income, inefficient delivery of basic services, lack of healthy living environment, exclusion from urban areas, barriers to access to quality basic rights such as education, decision-making authority, and citizenship (Türkdoğan, 2003, pp.107-108). Individuals and groups experiencing social exclusion from the society for reasons such as social, economic, cultural differences, meet their need for social solidarity by establishing social ties between themselves and tend to settle together in the same neighborhoods. The phrase of spatial exclusion has equivalent expressions in Turkish such as "gecekondu", "kent çeperi", "çöküntü", and "varoş". These places are called with different names in international literature such as "slum", "ghetto", "squatter", "suburban", and "bidonville". The concept of "otherized places" used in this study expresses all spatial reflections of urban poverty and social exclusion.

Within the scope of this study, we review the international literature on "otherized places" (ghetto, slum, squatter, skid row, favela, bantustan, shanty, ranchos, suburban, bidonville, and slum); and select 42 "otherized place" studies, which include the keywords of poverty, urban poverty, social exclusion, social inclusion, and social policy, scanned in Web of Science Core Collection indexes and published in the past decade. Following the framework of social problems that we reach through the mentioned content analysis; we commentate these problem areas from a social policy perspective. Accordingly, we seek answers for the following main questions: "Which types of the 'otherized places' were handled within the reviewed articles?" 
and "What were the basic social problems, primary needs, and requested services in these places in line with the literature review?" We reach remarkable findings in means of revealing a profile of the problems experienced in "otherized places" from different geographies under the guidance of the abovementioned method and research questions. In general, 21 of the reviewed articles are qualitative studies, 19 of them are quantitative studies, and 2 articles employed the mixed method which involves a combination of qualitative and quantitative research. 4 of the reviewed articles were carried out in slum settlements, 6 in the ghetto, 6 in suburban (in other words, banlieue), and 4 in squatter (one of them is the article regarding some slums in Istanbul and Ankara). The remaining 2 studies were conducted in the area of the favela settlements. Besides, the field research of 7 out of 42 articles was conducted in Nairobi, Kenya. The field research of 7 articles has been carried out in different cities of India while 7 scanned articles collected research information from various cities of the United States of America. 2 studies are based on the data gathered from residents of South Africa, Spain, Brazil, and Indonesia, and one study is conducted in Mexico, Peru, Uruguay, Argentina, Chile, Jordan, Finland, Britain, and China. While most of the studies conducted in Nairobi, Kenya focus on economic deprivation, the focus of the articles carried out in different cities of the United States is mostly on issues such as racism, ethnic discrimination, urban poverty, inability to benefit from health services, and crime. In 7 studies conducted in different cities of India, the issues such as problems about infrastructure and urban services, access to clean drinking water, conflicts between religious groups, and ignoring real problems by materializing the slum tourism of otherized poor places are discussed. The fact that the studies are concentrated in these three countries, shows that the social problems in otherized places of these countries have become annoying. Each of the 7 studies conducted in Nairobi, the capital city of Kenya, emphasizes that people are not able to meet their basic needs and that urban poverty has been felt at a high level by the residents. Additionally, to not being able to benefit from nutrition, accommodation, and official health services, inadequate infrastructure services, inability to meet transportation expenses, inability to access education, gender discrimination, and domestic violence are also among the social problems mentioned. Hence, the studies highlighted the need for poor otherized residents for access to clean water, infrastructure, and other basic services. Based on the above-mentioned findings, we conclude 
that individuals and groups who do not meet their basic vital needs and cannot benefit from basic welfare services equally like every member of the society cannot lead a life worthy of human dignity. Under these conditions, it does not seem possible for individuals and groups residing in otherized places to have a sense of belonging to the majority of the society, to participate in social life adequately, and from this situation arises one set of negative consequences for social peace and integration within the society. Neoliberal economic policies, which lead to increased poverty and a widening gap between rich and poor in sub-Saharan countries such as Kenya, significantly limit the amounts of public funding to be allocated to social policies and thus social services. On the other hand, India seems to be a country where the gap between the most developed and the poorest areas is getting deeper due to reasons such as the social caste system, unfair distribution of income, and unequal and unbalanced distribution of resources. In the reviewed field researches conducted specifically in this country, have revealed several problems such as inability to meet basic needs and to benefit from urban services, and conflict situation between religious groups. It could be shown clearly that the caste system, which is a macro level problem of Indian society, may easily lead to discriminatory practices- having potential negative consequences in the future. It is observed that ethnic minorities and individuals belonging to social sub-castes in the country are the most affected groups by this discriminatory and unfair approach. The fact that social justice does not work at the same level for all segments of society is a serious obstacle to social development in these societies. In the 21st century macro level discriminatory practices such as the Indian caste system should be questionable in line with the goals of social development and justice.

First, the public policymakers and local authorities must take responsibility for social policies and social services to meet the basic vital needs of people and then facilitate their access to urban infrastructure services and other social rights. This study with a social policy perspective focuses on social problems experienced in otherized places and emphasizes the importance of the inclusive measures necessary for social and human development. Spatial segregation, urban poverty, social exclusion, and related problems have mostly structural nature and economic deprivation, and social inequalities arise in connection with these problems. According to the scanned studies 
focusing on the problems of otherized places such as limited access or inability to access social welfare services, low socioeconomic and educational level, not being able to participate in employment, social deviation difficulties, and gender discrimination, it is obvious that the most important needs of the people of these disadvantaged regions are basic vital needs. Once they have access to safe food, clean water, infrastructure, and other urban services, they should be able to benefit from social welfare services such as education and health services. Making available all these opportunities for all segments of societies could substantially contribute to establishing a fairground for social integration. By providing the necessary opportunities for each citizen to lead a life worthy of human dignity and to participate in society, their loyalty and feeling of attachment to the country could be increased. In this context, the spread of social justice to all segments of the society is an obligation for social integration, social peace, and social development. For this reason, it is essential to implement applicable social policies and protective, preventive, curative and improving social work practices.

\section{Kaynakça / References}

Adaman, F. ve Keyder, Ç. (2006). Türkiye'de büyük kentlerin gecekondu ve çöküntü mahallelerinde yaşanan yoksulluk ve sosyal dişlanma. 25 Şubat 2020 tarihinde, http://ec.europa.eu/employment_social/social_inclusion/ docs/2006/study_turkey_tr.pdf adresinden erişilmiştir.

Ajlouni, M.T. (2016). Social determinants of health in selected slum areas in Jordan: challenges and policy directions. The International Journal of Health Planning and Management and Development Framework, 31, 113-125.

Akkoyunlu Ertan, K. (2007). Paris banliyö hareketini anlamak: Manuel Castells'i yeniden okumak. Amme İdaresi Dergisi, 40(1), 57-83.

Alptekin, K., Sili, A., Yılmazçoban, A.M. ve Ustabaşı, D. (2013). Kentsel dönüşüm eşiğinde bir alğ araştırması: Konya Yeni Mahalle örneği. KTO Karatay Üniversitesi Yayını, yayın no: 1, Konya: Dizgi Ofset.

Asiliskender, B. (2006). Kayseri eski kent merkezi'nde cumhuriyet'in ilanından günümüze mekan ve kimlik deneyimi. Erciyes Üniversitesi Fen Bilimleri Enstitüsü Fen Bilimleri Dergisi, 22(1), 203-212.

Ataöv, A. ve Osmay, S. (2007). Türkiye'de kentsel dönüşüme yöntemsel bir yaklaşım. ODTÜ Mimarlk Fakültesi Dergisi, 24 (2), 57-82. 
Awad, I. (2014). Journalism, poverty, and the marketing of misery: News from Chile's "largest ghetto." Journal of Communication, 64, 1066-87. DOI: 10.1111/jcom.12124

Bassett E., Gulyani S. ve Talukdar D. (2012). A tale of two cities: A multi-dimensional portrait of poverty and living conditions in the slums of Nairobi and Dakar. Presented at the Annual Association of Collegiate Schools of Planning (ACSP) Conference, Cincinnati, 2012 (Nov. 1-4). 23 Haziran 2020 tarihinde, http://people.virginia.edu/ emb7d/docs/Taleof2ACSP.pdf adresinden erişilmiştir.

Bengs, A., Hägglund, S., Wiklund-Engblom, A. ve Staffans, S. (2015). Designing for suburban social inclusion: A case of geo-located storytelling. IxDEA, 25, 8599.

Bıçkı, D. (2006). Kentsel yeniden yapılanma çerçevesinde mekansal yarılma, kentsel yoksulluk ve Türkiye. Zencirkıran, M. (Der.) Dünden bugüne Türkiye'nin toplumsal yapısı, içinde. Ankara: Nova Yay.

Brodrecht, A. (2012). Poverty's numbing effect on collective action: a case study of squatter settlers in Lima, Peru. Globalizations, 9(6), 851-867. DOI: 10.1080/14747731.2012.739342

Buğra, A. (2008). Kapitalizm, Yoksulluk ve Türkiye'de sosyal politika. İstanbul: İletişim Yay.

Butz, A.M. (2016). Theorizing about poverty and paternalism in suburban America: The case of welfare sanctions. Poverty and Public Policy, 8 (2), 129-140.

Corboz, J. (2013). Asentamientos and cantegriles: new poverty and the moral dangers of proximity in Uruguayan squatter settlements. Latin American Research Review, 48 (3), 44-62.

Çakır, S. (2007). Kentleşme ve gecekondu sorunu. Isparta: Fakülte Kitabevi.

Çekirdekci, Ş.Ö. (2020). There is no place like home: Poverty and the squatter house. Journal of Consumer Behaviour, 19 (3), 252-263.

De Antuñano, E. (2019). Mexico city as an urban laboratory: Oscar Lewis, the "culture of poverty" and the transnational history of the slum. Journal of Urban History, 45 (4), 813-830.

De, I. ve Nag, T. (2016). Deprivation in slums and child poverty: study on Kolkata. International Journal of Social Economics, 43(7), 739-759.

Deniz, A.Ç., Ekinci, Y. ve Hülür, A.B. (2016). Suriyeli sığınmaciların karşılaştı̆̆ sosyal dışlanma mekanizmaları. Sosyal Bilimler Araştırma Dergisi, 27, 17-40.

Dürr, E. (2012). Urban poverty, spatial representation and mobility: touring a slum in Mexico. International Journal of Urban and Regional Research, 36(4), 706-724. 
Erdoğdu, S. ve Kutlu, D. (2014), Dünya'da ve Türkiye'de çalışan yoksulluğu: işgücü piyasası ve sosyal koruma politikaları bağlamında bir değerlendirme, Çalşma ve Toplum Dergisi, 2, 63-114.

Fortujin, J. ve Ostendorf, W. (2004). Gender and urban poverty: single mothers in Amsterdam. Geo Journal, 61, 239-246.

Frenzel, F. (2013). Slum tourism in the context of the tourism and poverty (relief) debate. Die Erde, 144, 117-128.

Genç, Y., Taylan, H.H. ve Barış, İ. (2015). Roman çocuklarının eğitim süreci ve akademik başarılarında sosyal dışlanma algısının rolü. The Journal of Academic Social Science Studies, 33, 79-97.

Girbés-Peco, S., Macías-Aranda F. ve Álvarez-Cifuentes, P. (2015). From a ghetto school to a learning community: a case study on the overcoming of poverty through a successful education, Sciences, 4 (1), 88-116.

Goudet S.M., Kimani-Murage E.W., Wekesah F vd. (2017). How does poverty affect children's nutritional status in Nairobi slums? A qualitative study of the root causes of undernutrition. Public Health Nutrition, 20(4), 608-619.

Gowayed, H. (2018). The Unnecessary nudge: education and poverty policy in a Cairo slum. Sociological Forum, 33(2), 482-504.

Gökçearslan Çifci, E. (2008). Kapkaç suçundan hüküm giyenlerin, sosyo-demografik özellikleri, sosyal dışlanma süreçleri, suç ve diğer sapma davranışlar açısından incelenmesi. Yayımlanmış Doktora Tezi. Hacettepe Üniversitesi Sosyal Bilimler Enstitüsü Sosyal Hizmet Anabilim Dall, Ankara.

Guldi, J. (2019). World neoliberalism as rebellion from below? British squatters and the global interpretation of poverty, 1946-1974. Humanity: An International Journal of Human Rights, Humanitarianism, and Development, 10(1), 2957. https://doi.org/10.1353/hum.2019.0001.

Gulyani, S. ve Talukdar, D. (2010). Inside informality: the links between poverty, microenterprises, and living conditions in Nairobi's slums. World Development, 38 (12), 1710-1726.

Habeeb, R. and Javaid, S. (2019). Social inclusion of marginal in the great climate change debate: case of slums in Dehradun, India. SAGE Open, JanuaryMarch, 1-9.

Hanrahan, F. (2015). The poverty tour: life in the slums of Mumbai and Manila as seen in Danny Boyle's "Slumdog Millionaire" and Merlinda Bobis's" The Solemn Lantern Maker. JSTOR, 37 (1), 101-119. 
Hipp, J.R. ve Yates, D.K. (2011). Ghettos, thresholds and crime: does concentrated poverty really have an accelerating increasing effect on crime. Criminology, 49 (4), 955-990.

Izugbara, C. (2011) Poverty, masculine violence and the transformation of men: ethnographic notes from Kenyan slums. Pringle, K., Hearn, J., Ruspini, E. and Pease, B. (Der.) Men Masculinities around the World içinde (s. 21-32). New York: Palgrave Macmillan.

Jehoel-Gijsbers, G. and Vrooman, C. (2004). Social exclusion in the Netherlands. Workshop no 8. Hague: Social and Cultural Planning Office.

Karacaer, S., Sert, A.N. ve Öztürk, Y. (2017). Yoksul yanlı turizm yaklaşımı üzerine bir değerlendirme. Türk Turizm Araştırmalarn Dergisi, 1(3), 31-40.

Karaküçük, S. (2004). Bir mekansal paradigma olarak öteki. Eğitim Bilim Toplum, 2(8), 76-91.

Kartal, F. (2009). Suyun metalaşması, suya erişim hakkı ve sosyal adalet. Ankara: Türkiye ve Orta Doğu Amme İdaresi Enstitüsü.

Kümbetoğlu, B. (2012). Sosyolojide ve antropolojide niteliksel yöntem ve araștirma (3. Basım). İstanbul: Bağlam Yay.

Maitra, C. ve Rao, D.S.P. (2015). Poverty-food security nexus: evidence from a survey of urban slum dwellers in Kolkata. World Development, 72, 308325. https://doi.org/10.1016/j.worlddev.2015.03.006

Marshall, G. (1999). Sosyoloji sözlüğ̈̈. (O. Akınhay ve D. Kömürcü, Çev.). Ankara: Bilim ve Sanat Yayınları.

Miklian, J. ve Birkvad, I.R. (2016). Religion, poverty and conflict in a garbage slum of Ahmedabad. International Area Studies Review, 19(1), 60-75.

Mullins, P.R. ve Jones, L.C. (2011). Archaeologies of race and urban poverty: the politics of slumming, engagement, and the color line. Historical Archaeology, 45 (1) 33-50.

Murphy, A.K. (2010). The symbolic dilemmas of suburban poverty: challenges and opportunities posed by variations in the contours of suburban poverty. Sociological Forum, 25 (3), 541-569.

Mwiti, F. ve Goulding, C. (2017). Strategies for community improvement to tackle poverty and gender issues: An ethnography of community based organizations ('Chamas') and women's interventions in the Nairobi slums. European Journal of Operational Research, 268(3), 875-886. https://doi.org/10.1016/j.ejor.2017.12.009 
Nisbett, M. (2017). Empowering the empowered? Slum tourism and the depoliticization of poverty. GEOFORUM, 85, 37-45. https://doi.org/10.1016/j.geoforum.2017.07.007

Nofre, J. (2011) Youth policies, social sanitation, and contested suburban nightscapes. Perrone, C., Manella, G. ve Tripodi, L. (Der.) Everyday Life in the Segmented City içinde (s.261-281). Chicago, IL: Emerald Press. DOI: 10.1108/S10470042(2011)0000011015

Oliveira, P.V.S. (2019). In the flood zone: natural world and suburban poverty (Parnaíba-Pı, 1970's). História e Cultura, 8, 47-66.

Özgökçeler, S. ve Bıçkı, D. (2013). Kentsel yoksullukla mücadele için politik bir enstrüman: sosyal siyaset perspektifinden sosyal belediyecilik. Ömer Aytaç, Ö. ve İlhan, S. (Der.). Kentsel yoksulluğu yeniden düşünmek içinde (s. 1-23). Ankara: Birleşik Yay.

Öztürk, M. ve Çetin, B. (2009). Dünyada ve Türkiye'de yoksulluk ve kadınlar. Journal of Yasar University, 3(11), 2661-2698.

Palakshappa D. ve Fiks A. G. (2016). Implications of poverty for practices serving suburban families. Pediatrics, 138(6), e2016-2548.

Parikh, P., Fu, K., Parikh, H., McRobie, A. ve George, G. (2015). Infrastructure provision, gender and poverty in Indian slums. World Development, 66, 468-486.

Prayitno, G. Sari, N. ve Putri, I.K. (2019). Social capital in poverty alleviation through pro-poor tourism concept in slum area :Case study: Kelurahan Jodipan, Malang City). Int. J. GEOMATE, 16, 131-137.

Prianto, A.L. ve Amalia, A.A. (2019). Combatting slums, suistaining poverty: dynamic urban governance in Makassar, Indonesia. Otoritas: Jurnal Ilmu Pemerintahan, 9(1), 28-41.

Salon, D. ve Gulyani, S. (2010). Mobility, poverty, and gender: travel 'choices' of slum residents in Nairobi, Kenya. Transport Reviews, 30(5), 641-657. DOI: 10.1080/01441640903298998

Sapancall, F. (2005). Sosyal dışlanma (1. Basım). İzmir: Dokuz Eylül Yay.

Schnake-Mahl, A.S. and Benjamin D.S. (2017). Health care in the suburbs: an analysis of suburban poverty and health care. AcceHealth Affairs, 36 (10), 1777-1785. Doi:10.1377/hlthaff.2017.0545.

Seyyar, A. ve Genç, Y. (2010). Sosyal hizmet terimleri :Ansiklopedik "sosyal pedagojik çalısma" sözlüğ̈̈. Sakarya: Sakarya Yay. 
Simonelli G., Leanza Y., Boilard A., Hyland M., Augustinavicius J.L., Cardinali D.P., Vallières A., Pérez-Chada D. ve Vigo D.E. (2013). Sleep and quality of life in urban poverty: the effect of a slum housing upgrading program. SLEEP, 36(11), 1669-1676.

Small, M.L. (2015). De-exoticizing ghetto poverty: on the ethics of representation in urban ethnography. City \& Community, 14 (4), 352-58.

Steinbrink, M. (2012). 'We did the slum!' - Urban poverty tourism in historical perspective, Tourism Geographies, 14(2), 213-234. DOI: 10.1080/14616688.2012.633216

Subbaraman R., Nolan L., Sawant K., Shitole S., Shitole T., Nanarkar M., vd. (2015). Multidimensional measurement of household water poverty in a Mumbai slum: looking beyond water quality. PLoS ONE, 10(7), e0133241. doi:10.1371/journal.pone.0133241

Şahin, T. (2009). Sosyal dışlanma ve yoksulluk ilişkisi. Yardım ve Dayamışma Dergisi, $1(2), 71-80$.

Şengül, T. (2003). Kentsel yoksulluk ve mekânsal ölçek sorunu. Korkmaz, G.(Yay. haz.). 8 kasım dünya şehircilik günü 26. kolokyumu, 6-8 Kasım 2002, Ankara, Bildiriler içinde (s. 45-54). Ankara: TMMOB Şehir Planciları Odası.

Şenses, F. (2006). Küreselleşmenin öteki yüzü: yoksulluk (4. Baskı). İstanbul: İletişim Yay.

Turok, I. ve Borel-Saladin, J. (2016). The theory and reality of urban slums: pathwaysout-of- poverty or cul-de-sacs? Urban Studies, 1-22.

Türkdoğan, O. (2003). Türk toplumunda yoksulluk kültürü. Yoksulluk, I. Ulusal Yoksulluk Sempozyumu, 31 Mayıs-1 Haziran 2003, Cilt I, 105-110. İstanbul: Deniz Feneri Derneği Yay.

Ustabaşı Gündüz, D. (2018). Farkl sosyokültürel değerlere sahip birey ve gruplara yönelik sosyal içerme politikaları: Konya Tathcak mahallesi örneği.: Yayımlanmamış doktora tezi. Ankara Yıldırım Beyazıt Üniversitesi, SBE, Ankara.

Ünal, A. (2018). Kentsel dönüşüm ve aidiyet: Ankara'dan birörnek. Asia Minor Studies International Journal of Social Sciences, 6, 18-40.

Wacquant, L. (2015). Kent paryaları-ileri marjinalliğin karşılaştırlmalı sosyolojisi (2. bs.). İstanbul: Boğaziçi Üniversitesi Yay.

Yaşar, M.R. (2013). Yoksulların konutla imtihanı: Konut yoksulluğu. Ömer Aytaç, S. İ. (Der.). Kentsel yoksulluğu yeniden düşünmek içinde. Ankara: Birleşik Yay.

Yeğenoğlu, M. (2003). Öteki mekanda olmak: post kolonyal dünyada göçmenlik ve turizm. Kültür ve Turizm, 6 (2), 53-72.

Yıldırım, A. ve Şimşek, H. (2008). Sosyal bilimlerde nitel araştırma yöntemleri (6. Baskı). Ankara: Seçkin Yay. 
Yıldız, S. ve Yıldız, Z. (2018). Gecekondu turizmi: bir çözüm mü? Yoksa bir problem mi? Journal of Tourism and Gastronomy Studies, 6(4), 974-992.

Yılmaz, B. (2006). Yakındaki uzak: İstanbul'un bir kentiçi mahallesinde sosyal dışlanma ve mekânsal sürgün. Adaman, F. ve Keyder, Ç.(Der.) Türkiye'de büyük kentlerin gecekondu ve çöküntü mahallelerinde yaşanan yoksulluk ve sosyal dışlanma içinde (s. 27-39). Brussel.

Zhao, P. (2016). Planning for social inclusion: The impact of socioeconomic inequities on the informal development of farmland in suburban Beijing, Land Use Policy, 57, 431-443.

Zulu E., Beguy D., Ezeh A., Bocquier P., Madise N., Cleland J. ve Falkingham J. (2011). Overview of migration, poverty and health dynamics in Nairobi City's slum settlements. Journal of Urban Health, 88, 185-199.

\section{Kaynakça Bilgisi / Citation Information}

Ustabaşı Gündüz D. ve Sağlam, E. (2020). Öteki mekânlarda sosyal sorunlar: bir literatür taraması. OPUS-Uluslararası Toplum Araştırmaları Dergisi, 16(29), 2142-2178. DOI: 10.26466/opus.773019 